\title{
TANZIMAT'TAN CUMHURIYET'E MODERNLEŞME SÜRECINDE TARSUS'TA EĞiTiM
}

\section{Education in Tarsus at Process of Modernization from Administrative Reforms to Republic}

\section{Dr. Sacit UĞUZ}

\begin{tabular}{|c|c|}
\hline ÖZ & ABSTRACT \\
\hline $\begin{array}{l}\text { XIX. yüzyılda her alanda olduğu gibi } \\
\text { eğitim alanında da köklü ı̈lahatlara } \\
\text { gidilmiştir. Bu dönemde bir taraftan eski } \\
\text { eğitim kurumları mevcut halleriyle } \\
\text { korunurken, diğer taraftan da yeni ve modern } \\
\text { eğitim kurumlarının açılması ve ülke çapında } \\
\text { yaygınlaştırılması, genel politika olarak } \\
\text { benimsenmiştir. Özellikle Il. Abdülhamid'in } \\
\text { tahta çıkmasından sonraki yıllar, eğitim } \\
\text { alanında en fazla gelişmenin kaydedildiği } \\
\text { dönem olmuştur. Bu çalışmada, Tanzimat } \\
\text { reformları ile başlayan süreçte Tarsus'ta } \\
\text { bulunan klasik eğitim kurumlarının mevcut } \\
\text { durumları ile modern eğitim kurumlarının } \\
\text { gelişimi ve yaygınlaşması, Cumhuriyet'in } \\
\text { ilânından sonra meydana gelen değişiklerle } \\
\text { birlikte ele alınmıştır. Ayrıca Tarsus'ta } \\
\text { bulunan azınlı ve yabancı eğitim } \\
\text { kurumlarının kuruluşu, gelişimleri ve halk } \\
\text { üzerindeki etkileri özellikle misyonerlik } \\
\text { çalışmaları bağlamında incelenmiştir. }\end{array}$ & $\begin{array}{l}\text { As in every field, there had been strict } \\
\text { reforms in education in nineteenth century. In } \\
\text { this period, while the traditional education } \\
\text { instutitions were kept stable, forming new } \\
\text { education instutitions and making them } \\
\text { spread in the whole country was accepted as } \\
\text { a general politics. Especially, the years after } \\
\text { Abdülhamid the second had arised became } \\
\text { the period that most progress had been made } \\
\text { in education. In this work, starting from the } \\
\text { period of Administrative Refoms, the present } \\
\text { conditions of the traditional educational } \\
\text { instutitions and the progress and spread of } \\
\text { modern educational intutitions in Tarsus, } \\
\text { were studied with the changes happened after } \\
\text { the foundation of Republic. In addition, the } \\
\text { foundation, progress and effects of the } \\
\text { minority and foreign educational instutitions } \\
\text { on public were searched throughout the } \\
\text { missionary. }\end{array}$ \\
\hline $\begin{array}{l}\text { Anahtar sözcükler: } \\
\text { Rüşdiyesi, } \\
\begin{array}{l}\text { Tarsusus, eğitim, } \\
\text { misyonerlik. }\end{array}\end{array}$ & $\begin{array}{l}\begin{array}{l}\text { Rüsşdiyesi, Tarsus American } \\
\text { missionary. }\end{array} \\
\end{array}$ \\
\hline
\end{tabular}

\section{Giriş}

Osmanlı Devleti'nin yükselmesinde ve Türk-i̇slâm medeniyetinin inkişafında şüphesiz eğitim öğretim kurumlarının ve uygulanan eğitim sisteminin rolü büyüktür. Devletin kuruluşundan XIX. yüzyıla kadar medreseler ve sıbyan mektepleri eğitim öğretim faaliyetlerini tekelinde bulundurmuştur. Bunlar,

\footnotetext{
*Tarsus Otelcilik ve Turizm Meslek Lisesi Tarih Öğretmeni. (sacituguz@gmail.com)
} 
doğrudan devletin kontrolünde olmayan ve bağlı bulundukları vakıflar vasıtasıyla idaresi sağlanan, bu nedenle de sosyal ve dinî yönü ağır basan kurumlardır. Dolayısıyla devletin güçlü, toplumun istikrarlı ve vakıfların da gerçek vazifelerini yerine getirdiği kurumlar olduğu müddetçe, bu eğitim müesseseleri de asıl işlevleri olan ilmî faaliyetlerle meşgul olmuşlar ve topluma hizmet vermişlerdir. Ancak ne var ki XVIl. yüzyıldan itibaren devletin zayıflamaya, sosyal ve ekonomik düzenin de bozulmaya başlaması, vakıf müesseselerinin ve ona bağlı olan medreselerin de bozulmasına neden olmuştur. XVIIl. yüzyılın başlarından itibaren devletin değişik kurumlarında başlayan yenileşme hareketlerine, medrese ve ulema sınıfı kendisini kapatmıştır. Bu nedenle eğitim ve öğretimde yenilik, ancak ulemanın etkisinin az olduğu askerî mekteplerde başlamıştır.'

Osmanlı eğitim sisteminde ilk köklü yenilikler, XIX. yüzyılda Sultan 11. Mahmud ile birlikte başlamıştır. Batı dünyasında her alanda görülen ilerlemenin ancak eğitim yoluyla Osmanlı Devleti'ne girebileceğini bilen Il. Mahmud, 1824 yılında ilköğretimi mecburî hale getirmiştir. Her ne kadar bu girişimin gayesi, Müslüman çocuklarının din eğitimi yapan sıbyan mekteplerine devamını sağlamak ise de bu icraat, eğitim alanında yapılan köklü ıslahatların başlangıcı sayılır.

Osmanlı eğitim sisteminin modernleşmesi adına yapılan en önemli ıslahatlar ise 1 Eylül 1869 yılında yayımlanan Maârif-i Umûmiye Nizamnâmesi ile gerçekleştirilmiştir. ${ }^{2} \mathrm{Bu}$ nizamname ile eğitimde ilk defa sistemleşme ve kanunlaşmaya gidilmiştir. Merkez teşkilâtı yeniden yapılandırılırken taşrada da önemli düzenlemeler uygulamaya konulmuş ve vilâyetlere maârif müdürleri tayin edilerek maârif meclisleri oluşturulmuştur. Yine bu nizamnâme ile köylerde ve mahallelerde sıbyan, hane sayısı beş yüzü geçen kasabalarda rüşdiye, bin evi geçen kasabalarda idâdî ve vilâyet merkezlerinde de sultânî kurulması ve bunların üstünde de meslek ve ihtisas mektepleri ve darülfünûn bulunması öngörülmüştür. ${ }^{3}$ Il. Meşrutiyet'e kadar geçerliliğini koruyacak olan Maârif-i Umûmiye Nizamnâmesi'ne göre ülkede öğretim basamakları şu şekilde oluşmuştur; ilköğretim (Sıbyan Mektepleri/Medreseler ve ibtidaî Mektepler),

\footnotetext{
' Bayram Kodaman, Abdülhamid Devri Eğitim Sistemi, Ankara 1999, ss. IX-XI.

${ }^{2}$ Mahmud Cevad İnbü'ş Şeyh Nâfi, Maârif-i Umumiye Nezâreti Tarihçe-i Teşkîlât ve İraatı -XIX. Asır Osmanlı Maârif Tarihi- (Haz. Taceddin Kayaoğlu) Ankara 2001, s. 92.

3 ilhan Tekeli, “Tanzimat'tan Cumhuriyet'e Eğitim Sistemindeki Değişmeler”, Tanzimat'tan Cumhuriyet'e Türkiye Ansiklopedisi, ìstanbul 1985, 11, 470.
} 
Orta öğretim (Rüşdiye ve İdâdî Mektepleri, Sultaniler) ve Yükseköğretim (Darülfünun). ${ }^{4}$

II. Meşrutiyet'ten sonra ise eğitim alanındaki sorunlar, yeni yönetimin ele alması gereken en önemli hususlardan birisi olarak karşısına çıkmışırı. ilk defa bu dönemde eğitim-öğretimin birleştirilmesi yönünde bazı adımlar atılmış, ilköğretim için özel vergiler konulmuş, kullanılmakta olan Arap alfabesinde değişiklikler yapılarak daha kolay öğrenilen bir alfabe geliştirilmeye çalışılmış ve kadınların eğitimine önem verilmiştir. Aslında bu dönemde yapılan ıslahatlar, Cumhuriyet döneminde gerçekleştirilen eğitim hamlesine ilişkin düşüncelerin geliştiği ve şekillendiği bir hazırlık evresi niteliği taşımaktadır. ${ }^{5}$

Tanzimat ile birlikte eğitim alanında yapılan ıslahatların bir sonucu olarak diğer Osmanlı şehirlerinde olduğu gibi, Tarsus'ta da Müslümanlara hitap eden eğitim-öğretim kurumlarını klasik ve modern olarak iki grupta değerlendirmek mümkündür. Tarsus'ta bulunan sıbyan mektepleri ve medreseler klasik eğitim kurumlarını, ibtidaîler ve rüşdiye ise modern eğitim kurumlarını oluşturmaktadır. Ayrıca azınlık ve yabancı okullarının da şehirdeki eğitimöğretim faaliyetleri içerisinde önemli bir yere sahip olduğu görülmektedir.

\section{Klasik Eğitim Kurumlarn}

\subsection{Sibyan Mektepleri}

Sıbyan mektepleri, Osmanlı Devleti'nin ilk aşama eğitim ve öğretim kurumlarıdır. Bu mektepler genellikle bir külliye içerisinde, câmi ya da medrese yanlarında bulunmakla birlikte, ayrı ayrı her köy ve mahallede de bulunabilmektedir. İmparatorluğun parlak dönemlerinde ihtiyaca cevap verebilen bu kurumlar, ilerleyen yıllarda kendisini yenileyemediği için zamanın gerisinde kalmıştır. Diğer birçok kurumda olduğu gibi sıbyan mekteplerinde de islahat girişimleri Il. Mahmud ile birlikte başlamıştır. Ancak yapılmaya çalışılan bütün sslahatlara rağmen sıbyan mekteplerinde bir türlü usûl-i cedîdeye tam olarak geçilememesi, 1872 yılında sıbyan mektepleri derecesinde olan ve usûl-i cedîde ile eğitim yapan ibtidaî mekteplerin açılmasına sebep teşkil etmiştir. Bu tarihten sonra ilköğretim seviyesinde de görülmeye başlayan ikilik, usûl-i atîka ile eğitim yapan sıbyan mektepleri ve usûl-i cedîde ile eğitim yapan ibtidaî mektepler arasında sürüp gitmiştir. Maârif Nezâreti'nin ikiliği ortadan kaldırmak amacıyla ibtidaî mekteplere ağırlık vermesi ve bu mekteplerin imparatorluğun her

${ }^{4}$ Yakup Karataş, Sultan II. Abdülhamid Döneminde Erzurum, (Yayımlanmamış Doktora Tezi), Atatürk Üniversitesi Sosyal Bilimler Enstitüsü, Erzurum 2010, s. 226.

${ }^{5}$ Tekeli, “Tanzimat'tan Cumhuriyet'e Eğitim Sistemindeki Değişmeler”, s. 473. 
$\underline{322}{ }^{*}$ TAED 47

tarafinda yayılmasıyla, sıbyan mektepleri de giderek ikinci plana düşmeye başlamıştır.

Tarsus'a bakıldığında ise 1671 yılında şehre uğrayan Evliya Çelebi, "mekteb-i tıflân" olarak belirttiği sıbyan mekteplerinin sayısını 7 olarak vermektedir. ${ }^{7}$ Inceleme kapsamına giren Tanzimat sonrası dönemde, Tarsus'ta bulunan sıbyan mektebi sayıları ile ilgili en önemli veriler, Adana Vilâyet Salnâmelerinde yer almaktadır. Buna göre Tarsus merkezde, 1877 ve 1881 yıllarında $60^{8}, 1890$ yılında $66^{9}$ ve 1902 yilında da 51 adet $^{10}$ sıbyan mektebi bulunmaktadır. $\mathrm{Bu}$ dönemde Tarsus'un 25 civarında mahallesi olduğu düşünüldügünde mahalle başına en az iki, bazılarına da üç mektep düştüğü anlaşılmaktadır. Bu durum, kalabalık nüfuslu bir şehir olan Tarsus'ta, mahallelerdeki nüfus yoğunluğunun bir göstergesi olarak görülmelidir.

1901 yılına ait Maârif Salnâmesinde ise Tarsus'un köylerinde 70 adet sıbyan mektebi bulunduğu belirtilmektedir." Bu tarihte Tarsus'a bağlı 181 köy olduğu düşünülürse köylerdeki okullaşmanın şehir merkezine göre oldukça geride olduğu ortaya çıkmaktadır. Bunun en büyük nedeni olarak, birçok köyün nüfusunun okul açacak kadar fazla olmaması gösterilebilir.

Bu dönemde özellikle köylerde yer alan sıbyan mekteplerinde muallim eksikliğinden dolayı imamlardan ve müezzinlerden faydalanıldı̆̆ Ancak bazen bunun tam tersi durumlarda da söz konusu olduğu da görülmektedir. Örneğin, 1891 yılında Çıldırım köyü ahalisinden Abdullah ve Boşo Abdullah isimli iki kişi, maaşı kendileri tarafindan verilmek üzere, hem sıbyan mektebi muallimliğini hem de imamlık vazifesini yürütmek için muktedir bir muallim tayin edilmesini istemişlerdir. Bunun üzerine Mekâtib-i ibtidâiye idaresi tarafından Adana Muallimîn-i ibtidaîsi mezunlarından Hasan Efendi 15 Ocak 1894 tarihinde Çıldırım köyü sıbyan mektebine muallim olarak tayin edilmiştir. ${ }^{2}$

\footnotetext{
${ }^{6}$ Kodaman, Abdülhamid Devri Eğitim Sistemi, ss. 57-58, 66.

${ }^{7}$ Evliya Çelebi, Seyahatnâme, (Haz. Yücel Dağlı-Seyit Ali Kahraman-Robert Dankoff), (9. Kitap), istanbul 2005, s. 167.

8 Adana Vilâyet Salnâmesi (AVS), 1294, Salnâmenin sonunda ek olarak verilen çizelgeden alınmıştır; AVS, 1299, s. 42.

${ }^{9} A V S$, 1308, s. 98.

${ }^{10}$ AVS, 1320, s. 190.

"Maârif Salnâmesi, 1319, s. 363.

${ }^{12}$ BOA. MF.MKT. 193/49.
} 


\subsection{Medreseler}

Osmanlı Devleti'nin kuruluşundan Tanzimat dönemine kadar eğitimöğretim kurumlarının temelini medreseler teşkil etmiştir. ${ }^{13}$ Öğrenci kaynağını sıbyan mekteplerinin oluşturduğu medreseler, dönemin orta ve yükseköğretim kurumları olarak kabul edilmektedir. ${ }^{14}$

Çok eskiden beri bir ilim ve kültür merkezi olan Tarsus'ta, Osmanlı döneminde eğitim ve kültür hayatının şekillenmesinde şüphesiz medreselerin rolü çok büyük olmuştur. XVl. yüzyılda Tarsus şehrinde Ulaşzâde Rüstem Bey, Çakmakiyye (Debbağhâne) ve Mahmud Bey bin Turgud isimlerinde üç medrese bulunduğu görülmektedir. Bu medreseler yarı yerleşik hayatı sürdüren Türkmenlerin gerek ilmî, hukukî ve dinî seviyelerini arttırmak, gerekse de yerleşik hayata geçmelerini teşvik etmek açısından oldukça önemlidir. Nitekim bu medreseler vasitasıyla Türkmenler içerisinden din âlimlerinin yetişmesi ve bu sayede i̇slâm hukukunun daha iyi anlaşılması, bölgede Şiî propagandalarına karşı ehl-i sünnet inancının kuvvetle korunmasına zemin hazırlamıştır. Bu durumun Tarsus ve çevresinde Şiî kökenli isyanların taraftar bulamamasındaki en önemli etkenlerden olduğu söylenebilir. ${ }^{15}$ Evliya Çelebi, Tarsus şehrinde 6 adet medresenin bulunduğunu belirtmektedir. ${ }^{16}$ Zamanla şehrin gelişimine ve nüfusun artışına paralel olarak medrese sayısının da arttığı görülmektedir. Adana Vilâyet Salnâmelerine göre Tarsus'ta 1881 yılında 19 medrese bulunurken ${ }^{17}$, bu rakam 1902 yılına kadar 36'ya ulaşmıştır. ${ }^{18}$ Şemseddin Sami ve Vital Cuinet ise eserlerinde, Tarsus şehrinde 19 medrese bulunduğunu belirtmektedirler. ${ }^{19}$

Tarsus'ta bulunan medreseler hakkında en ayrıntılı bilgiyi ise Maârif Salnâmelerinden edinmek mümkündür. Buna göre Tarsus şehrinde 1898 ile 1903 yılları arasında 12, köylerde ise 5 adet medrese bulunmaktadır.

\footnotetext{
${ }^{13}$ Fatma Ürekli, “Tanzimat Dönemi Osmanlı Eğitim Sistemi Ve Kurumları”, Manas Üniversitesi Sosyal Bilimler Dergisi, 2002-3, s. 385.

${ }^{14}$ Cahit Baltacı, XV-XVI. Asırlarda Osmanlı Medreseleri, ìstanbul 1976, ss. 20-25; Yahya Akyüz, Türk Eğitim Tarihi; M.Ö.100o-M.S.2010, Ankara 2010, s. 215.

${ }^{15}$ Ali Sinan Bilgili, Osmanlı Döneminde Tarsus Sancağı ve Tarsus Türkmenleri, Ankara 2001, s. 134.

${ }^{16}$ Evliya Çelebi, Seyahatname, s. 167.

${ }^{17}$ AVS, 1299, s. 42.

${ }^{18}$ AVS, 1320, s. 190.

${ }^{19}$ Şemseddin Sami, Kamus-ı Türkî, Dersaadet 1317, IV, 3008; Vital Cuinet, La Turquie d'Asie, Paris 1892, Il, 48.
} 
Tablo 1: 1898 Yılında Tarsus'ta Bulunan Medreseler ${ }^{20}$

\begin{tabular}{|c|c|c|c|c|c|}
\hline $\begin{array}{l}\mathrm{S} . \\
\mathrm{Nr}\end{array}$ & Medresenin İsmi & Medresenin Mahalli & Müderris & $\begin{array}{l}\text { Talebe } \\
\text { Adedi }\end{array}$ & $\begin{array}{l}\text { Medresenin } \\
\text { Bânîsi }\end{array}$ \\
\hline 1 & $\begin{array}{l}\text { Kubad Paşa } \\
\text { Medresesi }\end{array}$ & $\begin{array}{l}\text { Debbağhâne } \\
\text { Mahallesi }\end{array}$ & Hâfiz Efendi & 33 & Kubad Paşa \\
\hline 2 & $\begin{array}{l}\text { Mehmed Efendi } \\
\text { Medresesi }^{21}\end{array}$ & Kasaba içinde & $\begin{array}{l}\text { Hacı } \\
\text { Mehmed } \\
\text { Efendi }\end{array}$ & 23 & Mehmed Efendi \\
\hline 3 & $\begin{array}{l}\text { Niyazi Efendi } \\
\text { Medresesi }\end{array}$ & Sofular Mahallesi & $\begin{array}{l}\text { Ahmed } \\
\text { Efendi }\end{array}$ & 73 & $\begin{array}{l}\text { Hoca Ayşe } \\
\text { Hanım }\end{array}$ \\
\hline 4 & $\begin{array}{l}\text { Kurâi Efendi } \\
\text { Medresesi }\end{array}$ & Müftü Mahallesi & $\begin{array}{l}\text { Mustafa } \\
\text { Efendi }\end{array}$ & 82 & Hacı Ali Ağa \\
\hline 5 & $\begin{array}{l}\text { Süleyman } \\
\text { Efendi } \\
\text { Medresesi }\end{array}$ & Müftü Mahallesi & $\begin{array}{l}\text { Mustafa } \\
\text { Efendi }\end{array}$ & 31 & $\begin{array}{l}\text { Hacı Süleyman } \\
\text { Efendi }\end{array}$ \\
\hline 6 & $\begin{array}{l}\text { Koyuncu } \\
\text { Medresesi }\end{array}$ & Kasaba içinde & $\begin{array}{l}\text { Tahsin } \\
\text { Efendi }\end{array}$ & 31 & Ahâlî \\
\hline 7 & $\begin{array}{l}\text { Meferli }^{22} \\
\text { Medresesi }\end{array}$ & Kasaba içinde & $\begin{array}{l}\text { Hafiz } \\
\text { Abdullah } \\
\text { Efendi }\end{array}$ & 29 & Ahâlî \\
\hline 8 & $\begin{array}{l}\text { Rüstem Bey } \\
\text { Medresesi }\end{array}$ & Kasaba içinde & Kâmil Efendi & 23 & Rüstem Bey \\
\hline 9 & $\begin{array}{l}\text { Kara Müftü } \\
\text { Medresesi }\end{array}$ & Kasaba içinde & $\begin{array}{l}\text { Hâfiz Ahmed } \\
\text { Efendi }\end{array}$ & 19 & Ahâlî \\
\hline 10 & $\begin{array}{l}\text { Şeyh Ömer } \\
\text { Efendi Medresesi }\end{array}$ & $\begin{array}{l}\text { Kasaba içinde } \\
(\text { Sofular Mah. })^{23}\end{array}$ & $\begin{array}{l}\text { Ömer Efendi } \\
\text { (Sofizâde) }\end{array}$ & 52 & Hüseyin Paşa \\
\hline
\end{tabular}

${ }^{20}$ Maârif Salnâmesi, 1316, s. 838, 839.

${ }^{21}$ Mehmed Efendi Medresesi'nin diğer adı Su Üstü Medresesidir. BOA. Y.A.RES. 123/65.

${ }^{22} \mathrm{Bu}$ medresenin ismi 1318 yılı Maârif Salnâmesinde "Makarlı Medresesi", 1321 salnâmesinde ise "Hıdırlı Medresesi" şeklide kayıtlıdır.

${ }^{23}$ Tarsus, 7 Şubat 1340, s. 1. 


\begin{tabular}{|c|l|l|l|c|l|}
\hline 11 & $\begin{array}{l}\text { Câmi-i Cedid } \\
\text { Medresesi }\end{array}$ & Kasaba içinde & $\begin{array}{l}\text { Abdülkâdir } \\
\text { Efendi }\end{array}$ & 46 & $\begin{array}{l}\text { Alay Beyi } \\
\text { Ahmed Ağa }\end{array}$ \\
\hline 12 & $\begin{array}{l}\text { Küçükminare } \\
\text { Medresesi }\end{array}$ & Kasaba içinde & $\begin{array}{l}\text { Hacı Emin } \\
\text { Efendi }\end{array}$ & 28 & Ahâlî \\
\hline 13 & $\begin{array}{l}\text { Gülek Merkez } \\
\text { Medresesi }\end{array}$ & $\begin{array}{l}\text { Panzinçukuru } \\
\text { Köyü }\end{array}$ & $\begin{array}{l}\text { Abdülkerim } \\
\text { Efendi }\end{array}$ & 43 & Ahâlî \\
\hline 14 & $\begin{array}{l}\text { Kargılı } \\
\text { Medresesi }\end{array}$ & Kargılı Köyü & $\begin{array}{l}\text { Durmuş } \\
\text { Efendi }\end{array}$ & 12 & $\begin{array}{l}\text { Hacı Mustafa } \\
\text { Ağa }\end{array}$ \\
\hline 15 & $\begin{array}{l}\text { Ulaş Medresesi } \\
16\end{array}$ & $\begin{array}{l}\text { Kocaulaş Köyü } \\
\text { Medresesi }\end{array}$ & $\begin{array}{l}\text { Abdullah } \\
\text { Efendi }\end{array}$ & 30 & Ahâlî \\
\hline 17 & $\begin{array}{l}\text { Boztepe } \\
\text { Medresesi }\end{array}$ & Yaylak & $\begin{array}{l}\text { Mustafa } \\
\text { Efendi }\end{array}$ & 11 & Sadullah Efendi \\
\hline
\end{tabular}

Tarsus'un XIX. yüzyılın sonlarında vilâyet dâhilinde medrese eğitimi bakımından önemli bir merkez konumunda olduğu görülmektedir. Zira bu dönemde Adana merkez kazası dışında vilâyet dâhilindeki diğer kazaların hiç birisinde Tarsus'taki kadar medrese bulunmamaktadır. Tarsus'taki medreselerde 1898 ve 1899 yillarında $565^{24}, 1900$ yılında $690^{25}$, 1901 yılında $664^{26}$, ve 1903 yılında da $584^{27}$ talebenin eğitim gördüğ̈̈, salnâme kayıtlarından anlaşılmaktadır. Bu rakam diğer eğitim kurumlarının öğrenci adetleri ile kıyaslandığında yüzyılın sonlarında Tarsus'ta en önemli eğitim-öğretim kurumlarının hâlâ medreseler olduğu sonucuna varılmaktadır.

Tarsus'ta bulunan birkısım medreseler 1899 yılında şehre gelen Girit muhacirlerinin geçici olarak yerleştirildikleri mahal olmaları bakımından da önemli bir işlev görmüştür. Bu dönemde gelen birçok muhacir, şehirde bulunan

${ }^{24}$ Maârif Salnâmeleri, 1316, s. 838; 1317, s. 936.

${ }^{25}$ Maârif Salnâmesi, 1318, s. 1038.

${ }^{26}$ Maârif Salnâmesi, 1319, s. 365.

${ }^{27}$ Maârif Salnâmesi, 1321, s. 333, 334. 
medreselerde kalıcı iskân mahallerine gönderilinceye kadar iki yıl süreyle misafir edilmişlerdir. ${ }^{28}$

Tarsus'a en son 1923 yılında yeni bir medrese yapılması kararlaştırılmıştır. İttihad ve Terakki Mektebi'nin hemen karşısına inşa edilecek ve Darü'l Hilâfe adını alacak olan bu medrese, açılma şansı bulamadan Tevhid-i Tedrîsat Kanunu çıkmış ve yurttaki bütün medreseler kapatılmıştır. ${ }^{29} 1925$ yılında kaymakamlık görevinde bulunan Mehmed Ali Bey zamanında, Tarsus'ta atıl durumda bulunan medreselerin tespiti yapılarak fiyatları belirlenmiş ve müzayede yoluyla satılması için vilâyete bildirilmiştir. ${ }^{30}$

\section{Modern Eğitim Kurumları}

\section{1. ỉbtidaî Mektepler}

Tanzimatçlar, eskiye dokunmadan yenisini yapmak siyasetine uygun olarak sıbyan mektepleri seviyesinde ibtidaî adıyla ilköğretime yönelik modern okulların açılması fikrini ilk olarak 1863'lerde gündeme getirmişlerdir. 1869 yılında yayımlanan Maârif-i Umûmiye Nizamnâmesiyle de ibtidaî okulların açılması yasalaşmışırı. Ancak Sultan Il. Abdülhamid dönemine kadar bu okulların memleket geneline yaygınlaştııılmasında başarı sağlanamamışır. Bu dönemde ise ilköğretim hizmetini bütün Osmanlı ülkesine yayarak Müslüman halkı cehaletten kurtarmak genel amaç olarak benimsenmiştir. Bu doğrultuda onun döneminde ülke genelinde özellikle ilköğretimden başlanarak âdeta bir eğitim seferberliğinin başlatıldığı ve bunun sonucunda da okullaşma oranında hızlı bir artış olduğu görülmektedir. ${ }^{31}$

1913 yılında Tedrîsat-ı ibtidaiye Kanun-1 Muvakkati çıkarılmış ve geçici olmasına rağmen Cumhuriyetin ilanından sonra da birçok maddesi geçerliliğini devam ettirmiştir. O tarihe kadar ibditaî ve rüş̧î adlarıyla bilinen okullar birleştirilmiş ve Mekâtib-i Umûmiye-i ibtidaiye adını almıştır. ilköğretimin süresi de 6 yıl olarak belirlenmiş ve 2'şer yıldan 3 bölüme ayrılmıştır. Bunlar; devre-i ûlâ, devre-i mutavassıta ve devre-i âliye olarak isimlendirilmiştir. ${ }^{32}$

Tarsus'ta yeni usûle göre eğitim yapan ilk mekteb Tarsus Birinci Numûne Mektebi adıyla açılmıştır. Okula ait ilk kayıt ise 1881 yılına aittir. Bu tarihte

${ }^{28}$ BOA. DH.MKT. 2336/30; BOA. A.MKT.MHM. 512/14.

${ }^{29}$ Tarsus, 3 Temmuz 1339, sayı: 99-297, s. 1.

${ }^{30}$ Tarsus, 12 Teşrinisânî 1341, sayı: 478-279, s. 1.

${ }^{31}$ Kodaman, Abdülhamid Devri Eğitim Sistemi, s. 67-68, 86.

${ }^{32}$ Akyüz, Türk Eğitim Tarihi, s. 268, 269. 
okulda birinci muallim olarak Hafiz ìsmail Efendi, ikinci muallim olarak da Şahabettin Efendi görev yapmaktadır. 97 öğrencinin eğitim gördüğü okul kadrosunda ayrıca iki kalfa ve bir de bevvab bulunmaktadır. ${ }^{33}$

1892 yilında Tarsus merkezde 4 adet ibtidaî mekteb tesis edilmiş ve 1893 yılı Ocak ayında muallimleri tayin edilerek eğitim öğretime başlanmıştır. Bu mektepler şehrin en eski ve en kalabalık mahalleleri olan Sofular, Sakızlı, Kızılmurad ve Musalla Mahallelerinde açılmış ve mahallerinin isimleriyle anılmışlardır. Böylece şehirdeki ibtidaî mekteplerin sayısı 5'e çıkmıştır. Bu dönemde Tarsus şehrinde ibtidaî mektebe devam eden öğrenci sayısı ise 500'ü geçmiştir. ${ }^{34}$

1899 yılında Tarsus Maârif Komisyonu reisliğine seçilen Tarsus eski müftüsü Ahmed Hilmi Efendi'nin oğlu, ulemâdan Yakub Efendi'nin gayretleri ve halkın da yardımlarıyla, 1901 tarihinde Tarsus merkezde bir kız bir erkek olmak üzere 2 ve köylerde 5 adet olmak üzere toplam 7 ibtidaî mektep tesis edilmiş, ögrencilerine de tek tip okul kıyafeti giydirilmiştir. Bir kısmı eski sıbyan mekteplerinin yeni usûle tebdîl edilmesiyle tesis edilen bu mektepler, padişahın doğum gününün sene-i devriyesi olan 2l Eylül 1901 tarihinde yapılan resmî merasimle hizmete açılmıştır. Tarsus merkezde açılan okullar, Gülşen-i Edeb İnas Mektebi ile Hamidiye (Afgan Mahallesi) Mekteb-i ibtidaîsi'dir. Diğer 5 okul ise nüfus olarak kalabalık olan Baltalı, Frengülüs, Yüksek, Hacıbozan ve Yenice köylerinde açılmıştır. ${ }^{35}$ Yeni açlan bu 7 okulla birlikte Tarsus şehir ve köylerindeki ibtidaî mekteplerin sayısı 12'ye çıkmıştır.

1903 yılında ise bu sayının 17'ye ulaştığı görülmektedir. Bu tarihte mekteplerin bulundukları mahalle ve köyler ise şöyledir: Sofular Mahallesi, Sakızlı Mahallesi, Müftü Mahallesi (2 adet), Musalla Mahallesi, Küçük Minare Mahallesi, Afgan Mahallesi, Şehir merkezi (2 adet), Panzinçukuru köyü (2 adet), Kargılı köyü, Baltalı köyü, Frengülüs köyü, Hacıbozan köyü, Yüksek köyü, Yenice köyü. ${ }^{36}$

Tarsus'ta yeni okulların tesisi, mevcut okulların eksiklerinin giderilmesi ve artan öğretmen maaşları, bütçeye hayli külfet getirmiştir. Bu nedenle yeni kaynaklar oluşturmak için çeşitli çalışmalar yapılmıştır. Örneğin, 1904 yılında o dönemde Tarsus şehrinde mevcut olan 7 adet ibtidaî mektebin masrafları 39 bin kuruşu bulmaktadır. Bu meblağ bir önceki yıla kadar zebhiye vergisinden ve Toroslardan şehre kar getirip satanlardan alınan vergilerden karşılanırken, yeni

\footnotetext{
${ }^{33}$ AVS, 1299, s. 58.

${ }^{34}$ BOA. MF.MKT. 158/37..

${ }^{35}$ BOA. MF.MKT. 600/34; BOA. MF.MKT. 598/4; BOA. MF.MKT. 599/12.

${ }^{36}$ Maârif Salnâmesi, 1321, s. 331.
} 
yapılan buz fabrikası nedeniyle toplanan vergi miktarı bir hayli düşmüştür. Bu nedenle öğretmen maaşlarının karşılanması zora girmiştir. Ayrıca mevcut okulların yeterli gelmemesinden dolayı 2 erkek ve 1 de kız mektebine ihtiyaç duyulan şehirde, maârif için gerekli olan bu paranın, Bac Köprüsü'nden geçecek olan yüklü develere ve pazar yerlerinde satılan hububat, koza, susam vesaireye konulacak ek vergilerle toplanması çözüm olarak sunulmuştur. ${ }^{37}$

ilerleyen yıllarda Tarsus'taki ibtidaî mekteplere yenileri eklenmiştir. Rehber-i Füyûz, Menba-ı İrfan ${ }^{38}$, Eskisaray, Menba-1 Füyûz, l. Kız Numûne ve 11. Kız Numûne Mektepleri, Osmanlı'nın son dönemlerinde ve Cumhuriyet'in ilk yıllarında açılan okullardır. ilk Tedrîsat Meclisi'nin 31 Ekim 1925 tarihinde aldığı karar gereğince 1926 yılı itibariyle bu okulların ismi aşağıdaki şekilde değiştirilmiştir. ${ }^{39}$

\begin{tabular}{lll} 
Eski Adı & & Yeni Adı \\
\hline Menba-ı Füyûz & - & Tınaztepe Erkek Mektebi \\
Menba-ı Irfan & - & Sakarya Erkek Mektebi \\
Eskisaray & - & Dumlupınar Erkek Mektebi \\
Erkek Numûne & - & Misak-1 Millî Erkek Mektebi \\
l. Kız Numûne & - & 29 Teşrinievvel Kız Mektebi \\
Il. Kız Numûne & - & Duatepe Kız Mektebi
\end{tabular}

1913 tarihli Tedrîsat-ı ibtidaiye Kanun-i Muvakkati, ülkede daha yeni yeni açılmaya başlayan anaokullarını da ilköğretim içerisinde saymıştır. 1915 yılında yayınlanan Ana Mektepleri Nizamnâmesi sonrasında ise ülke genelinde anaokulları yaygınlaşmaya başlamıştır. Tarsus'ta da ilk anaokulunun bu tarihten sonra açıldı̆̆ı anlaşılmaktadır. Zira 29 Ekim 1923 tarihli Tarsus gazetesinin haberinde; şehirde mevcut anaokulunun sebepsiz yere bir sene önce kapatıldığı, şimdi ise tekrar açılması yönünde vilâyet makamından Tarsus Kaymakamlı̆̆ına emir geldiği belirtilmektedir. ${ }^{40}$ Bunun üzerine anaokulu, 1924 yılında tekrar açılmış, Kadriye Hanım ${ }^{41}$ ve Rafia Hanım muallime olarak tayin edilmiştir. ${ }^{42} \mathrm{Bir}$

${ }^{37}$ BOA. DH.MKT. 818/20; BOA. I.DH. 1428/1322.

${ }^{38} \mathrm{Bu}$ kayıtlara Sakarya ilköğretim Okulu'nun arşivinde yapılan araştırmalar neticesinde ulaşılmıştır. Arşivde, Tarsus Rüşdiyesi ile Rehber-i Füyûz, Erkek Numûne ve Menba-ı İrfan Mekteplerinin sene sonu imtihan cetvelleri bulunmaktadır.

39 Tarsus, 31 Kanunievvel 1341, sayı: 487-288, s. 1.

${ }^{40}$ Tarsus, 23 Teşrinievvel 1339, sayı: 324-125, s. 1.

${ }^{41}$ Tarsus, 11 Ağustos 1340, sayı: 391-192, s. 1.

42 Tarsus, 18 Ağustos 1340, sayı: 399-200, s. 1. 
yıl sonra iki yeni okulunun daha açılmasıyla şehirdeki anaokullarının sayısı üçe çıkmışır. ${ }^{43}$

Tarsus'ta ayrıca yine 1924 yılında Türk Ocağı bünyesinde iki sınıflı bir gece mektebi açılmışırı. ${ }^{44} 1925$ yılı itibariyle Tarsus merkezde 2 kız ve 4 erkek olmak üzere 6 , köylerde ise 38 olmak üzere toplam 44 ilkokul bulunmakta ve bu okullarda 2.675 öğrenci öğrenim görmektedir. Anaokullarında okuyan öğrenci sayısı ise bu tarihte 233 kişiyi bulmuştur. ${ }^{45}$

Tarsus'ta bulunan ve haklarında malûmata ulaşılabilen ibtidaî mektepler şunlardır:

Sofular Mahallesi Mekteb-i ibtidaîsi: Sofular Mahallesi ibtidaî mektebi, 1892 yılında kurulmuş ve 1893 yılında Darü'l Muallimîn-i ibtidâiye mezunlarından Amasyalı Mustafa Efendi, aylık 300 kuruş maaşla birinci muallim olarak tayin edilmiştir. Bir yıl sonra Mustafa Efendi'nin yanında ikinci muallim olarak Ahmed Efendi'nin görev yaptığı görülmektedir. ${ }^{46} 1901$ yılında ise 130 öğrencinin eğitim gördüğü okulda, birinci muallim olarak Hafız İsmail Efendi, ikinci muallim olarak da Osman Efendi vazife yapmaktadır. ${ }^{47}$

Sakızı Mahallesi Mekteb-i ibtidaîsi: Sakızlı Mahallesi ibtidaî mektebi, 1892 yılında açılmış olup bir yıl sonra Darü'l Muallimîn-i ibtidâiye mezunlarından Yozgatlı İbrahim Hakkı Efendi, 300 kuruş maaşla birinci muallimlik vazifesi ile buraya tayin edilmiştir. ${ }^{48} 1901$ yılında ise 80 öğrencinin eğitim gördüğü okulda, bu tarihte birinci muallim olarak ìsmail Hakkı Efendi, ikinci muallim olarak da Ömer Efendi vazife yapmaktadır. ${ }^{49}$

Kızlmurad Mahallesi Mekteb-i ibtidaîsi: Kızılmurad Mahallesi'nde yer alan bu okul da 1892 yılında hizmete girmiştir. 1893 yılında da Sungurlulu Abdullah Efendi 300 kuruş maaşla birinci muallim olarak tayin edilmiştir. Bir yıl sonra Abdullah Efendi'nin yanında ikinci muallim olarak Fâik Efendi'nin vazife yaptığı görülmektedir. ${ }^{50} \mathrm{Bu}$ okul, 1901 yılı salnâmesinde Câmi-i Atik Mekteb-i ibtidaîsi adıyla yer almaktadır. Bu çelişkinin, birbirine komşu olan bu mahallelerin

43 Tarsus, 31 Kanunievvel 1341, say1: 487-288, s. 1.

44 Tarsus, 24 Eylül 1340, sayı: 397-198, s. 1.

45 Tarsus, 25 Ağustos 1341, sayı: 461-262, s. 1.

${ }^{46}$ BOA. MF.MKT. 158/37; AVS, 1312, s. 180.

${ }^{47}$ AVS, 1319, s. 196.

${ }^{48}$ BOA. MF.MKT. 158/37; AVS, 1312, s. 180.

49 AVS, 1319, s.196. Bu salnâmede okulun ismi "Hastane Civarındaki Mekteb-i ibtidaîsi" şeklinde kaydedilmiștir.

${ }^{50}$ BOA. MF.MKT. 158/37; AVS, 1312, s.181. 
$330{ }^{*}$ TAED 47

sınırlarının kesin çizgilerle ayrılmamasından ileri geldiği düşünülmektedir. Bu tarihte okulda 120 öğrenci öğrenim görmektedir. Birinci muallim olarak Abdullah Efendi vazifesine devam ederken, ikinci muallim olarak da Ahmed Efendi görev yapmaktadır. ${ }^{51}$

Musalla Mahallesi Mekteb-i ibtidaîsi: 1892 yılında hizmete giren bir diğer mektep olan Musalla Mahallesi ibtidaî Mektebi'ne, 1893 yılında 300 kuruş maaşla Habib Efendi birinci muallim olarak tayin edilmiştir. Bir yıl sonra ìsmail Efendi'nin de ikinci muallimlik vazifesini ifa ettiği görülmektedir. ${ }^{52} 1901$ yılında 75 öğrencinin bulunduğu okulda, Habib Efendi birinci muallim olarak vazifesine devam ederken ikinci muallimlik görevini ise Hafız Ahmed Efendi yürütmektedir. ${ }^{53} 1909$ yılında ise birinci muallimlik vazifesine Mehmed Şükrü Efendi tayin edilmiştir. ${ }^{54}$

Gülşen-i Edeb İnas Mektebi: Sadece kızların eğitim gördüğü kız ibtidâ̂ mektebidir. 2l Eylül 1901 tarihinde yapılan resmî merasimle ${ }^{55}$, kiralanmak suretiyle okula dönüştürülen bir binada eğitim-öğretime başlamıştır. ilk muallimesi Hikmet Hanım olup 22 Ekim 1901 tarihinde 300 kuruş maaşla bu göreve tayin edilmiştir. Bu tarihte okulda $50 \mathrm{kız} \mathrm{öğrenci} \mathrm{eğitim} \mathrm{görmektedir.}{ }^{56}$

Hamidiye (Afgan Mahallesi) Mekteb-i ibtidâ̂si: 21 Eylül 1901 tarihinde resmî merasimle açılışı yapılan ${ }^{57}$ Hamidiye ibtidaî mektebi, kız mektebi gibi kiralamak suretiyle okul hâline dönüştürülen bir binada hizmete başlamıştır. Bu tarihte 70 erkek öğrencinin eğitim gördüğü mektebin ilk muallimleri Süleyman Efendi ve Abdülkadir Efendi'dir. Medrese talebesi olan muallimlerin, Maârif komisyonu tarafından yapılan inceleme sonucunda usûl-i cedîdeye göre eğitim yapmaya kâdir olduğu anlaşılmış ve 14 Ekim 1901 tarihinde 300'er kuruş maaşla bu göreve tayin edilmişlerdir. ${ }^{58}$

Rehber-i Füyûz Mektebi: Tarsus Rüşdiyesi, 1913 yılında çıkan ibtidaî ve rüşdiyelerin birleştirilmesini öngören kanundan bir yıl sonra ibtidaî programlı rüşdiye statüsüne getirilerek Rehber-i Füyûz Mektebi adılla 6 sınıflı bir okula

${ }^{51} A V S, 1319$, s. 197.

${ }^{52}$ BOA. MF.MKT. 158/37; AVS, 1312, s.181.

${ }^{53}$ AVS, 1319, s. 197.

${ }^{54}$ BOA. MF.MKT. 1332/27.

${ }^{55}$ BOA. DH.MKT. 598/41.

${ }^{56}$ BOA. MF.MKT. 600/34; BOA. MF.MKT. 617/13.

${ }^{57}$ BOA. DH.MKT. 598/41.

${ }^{58}$ BOA. MF.MKT. 600/34; BOA. MF.MKT. 617/13. 
dönüştürülmüştür. ${ }^{59}$ Eğitim süresi devre-i ûla, devre-i mutavassıta ve devre-i âliye olmak üzere ikişer yıldan üç bölüm olarak belirlenmiştir. Okul ile ilgili kayıtlar incelendiğinde 1915 ile 1918 yılları arasını hâvî imtihan cetvellerinde, sadece devre-i mutavassıtanın ikinci yılı ile devre-i âliyenin birinci ve ikinci yıllarına ait kayıtların bulunduğu görülmektedir. 1920 yılına ait imtihan cetvelinin üzerinde ise " $B u$ tarihten itibaren altı sınıf olmuştur" ibaresi yer almaktadır. Bu durumda Rehber-i Füyûz Mektebi'nin 1920 yılına kadar, 1913 yılında çıkan kanun uyarınca altı yıl olan ilköğretim süresinin ikinci üç yılı için eğitim-öğretim veren bir okul olarak hizmet verdiği anlaşılmaktadır. ${ }^{60}$

Tablo 2: Rehber-i Füyûz Mektebi Öğrencilerinin Sınıflara Göre Dağılımı ${ }^{61}$

\begin{tabular}{|l|c|c|c|c|}
\hline \multirow{2}{*}{ SINIFLAR } & \multicolumn{3}{|c|}{ ÖĞRETIM YILLARINA GÖRE ÖĞRENCi SAYILARI } \\
\cline { 2 - 5 } & $1915-1916$ & $1916-1917$ & $1920-1921$ & $1922-1923$ \\
\hline Devre-i Ûlâ 1. Sınıf & - & - & 23 & 43 \\
\hline Devre-i Ûlâ 2. Sınıf & - & - & 22 & 19 \\
\hline $\begin{array}{l}\text { Devre-i Mutavassıta 1. } \\
\text { Sınıf }\end{array}$ & - & - & 12 & 45 \\
\hline $\begin{array}{l}\text { Devre-i Mutavassıta 2. } \\
\text { Sınıf }\end{array}$ & 21 & 37 & 8 & 36 \\
\hline $\begin{array}{l}\text { Devre-i Âliye 1. Sınıf } \\
\text { Sevre-i Âliye 2. Sınıf }\end{array}$ & 16 & 21 & 4 & 11 \\
\hline Toplam & 52 & 69 & 74 & 172 \\
\hline
\end{tabular}

Okulun 1915 yılında 52 kişi olan öğrenci sayısının 1922 yılında 172 kişiye çıktığı görülmektedir. Halkın modern eğitim kurumlarına olan eğiliminin artması ve özellikle de 1920 yılından itibaren okulda altı yıllık eğitim yapılmaya

59 Metin Yılmaz, M. Haluk Uzun, Kasım Aydın, M. Beşir Yavuz, Cumhuriyet Öncesi ve Cumhuriyet Sonrası lçel'de Eğitim, Mersin 1998, s. 19.

60 Tarsus Sakarya Ilköğretim Okulu Arşivi (TSiOA), Rehber-i Füyûz Mektebi'nin 1331-1332, 13321333, 1333-1334, 1336-1337 ve 1338-1339 öğretim yıllarına ait imtihan cetvelleri.

${ }^{61}$ Bu tablo Sakarya ilköğretim Okulu Arşivinde bulunan Rehber-i Füyûz Mektebi'ne ait sene sonu imtihan cetvellerindeki öğrenci sayıları esas alınarak hazırlanmıştır. 
$332{ }^{*}$ TAED 47

başlanmasının bu artışın başlıca nedenleri olarak görülmektedir. Ayrıca öğrenci sayısının ilk sınıflarda daha kalabalık olduğu ve son sınıfa doğru giderek azaldığı göze çarpmaktadır. Bu da birçok öğrencinin öğrenim süresini tamamlamadan okulu bıraktıklarını göstermektedir.

Rehber-i Füyûz Mektebi, 1923 yılında Tarsus Amerikan Koleji'nin yanındaki binaya taşınmış ve ismi önce Rehber-i Füyûz Numûne Mektebi ${ }^{62}$, daha sonra da Erkek Numûne Mektebi olarak değiştirilmiştir. ${ }^{63} 6$ yıl olan eğitim süresi 1925 yılından itibaren 5 yıl olarak yeniden düzenlenmiştir. ${ }^{64}$ ilk Tedrisat Meclisi'nin 31 Ekim 1925 tarihinde aldığı karar gereğince 1926 yılında okulun adı Misak-1 Milîi ilkokulu olarak tekrar değiştirilmiş ve 5 yıl eğitim veren bir ilkokul hâline getirilmiştir. ${ }^{65}$ Misak-1 Millî ilkokulu, 1997 yllına kadar hizmet verdikten sonra binası bu tarihte Amerikan Koleji'ni de bünyesinde bulunduran Sağlık ve Eğitim Vakfi'na ait Sev ilköğretim Okulu'na devredilmiştir.

Menba-1 İran Mektebi: Menba-1 İrfan Mektebi ile ilgili mevcut kayıtlar 1922, 1923 ve 1924 yıllarına aittir. 1922 yılı imtihan cetvelleri eksik olup devre-i evvelî 2 . sınıf ve devre-i mutavassıta 1 . sınıfına giden öğrencilerin kayıtları vardır. Diğer iki yıla ait kayıtlar ise tamdır. 1923 yılında anasınıfı mahiyetindeki sıbyan sınıfında 38, devre-i evvelî 1 . sınıfta 26, devre-i evvelî 2. sınıfta 37 ve devre-i mutavassıta 1. sınıfta da 18 olmak üzere toplam 119 öğrenci eğitim görmektedir. 1924 yılında ise devrelerin kaldırıldığı görülmektedir. Bu tarihte okulda 1. sınıfta 42, 2. sınıfta 39, 3. sınıfta 26 ve 4. sınıfta da 13 olmak üzere toplam 120 öğrenci eğitim görmektedir. ${ }^{66}$ Bu bilgiler ışı̆̆ında okulun 6 yıllık ilköğretimin ilk üç yılı için eğitim-öğretim yaptığı ortaya çıkmaktadır.

Menba-1 İran Mektebi'nin ismi, ilk Tedrîsat Meclisi'nin aldı̆̆ı karar mucebince, 1926 yılında Sakarya ilkokulu olarak değiştirilmiştir. ${ }^{67}$ Okul günümüzde de aynı isimle ilköğretim okulu olarak eğitim-öğretim hayatına devam etmektedir.

Itttihad ve Terakki Mektebi: Tarsus'ta bulunan bir diğer okul da ittihad ve Terakki Mektebi'dir. Tarsus'a 1910 yılı Ocak ayında gelen Ahmed Şerif in belirttiklerine göre; yeni öğretime başlayan okulda bu tarihte 110 öğrenci

62 Tarsus, 26 Mart 1340, sayı: 359-160, s. 3.

63 TSIOA, Erkek Numune Mektebi'nin 1923-1924 ve 1924-1925 yıllarına ait imtihan cetvelleri.

64 Tarsus, 3 Temmuz 1340, say1: 384-185, s. 1.

65 Tarsus, 31 Kanunievvel 1341, sayı: 487-288, s. 1.

66 TSIOA, Menba-1 Irfan Mektebine ait 1338-1339, 1339-1340 ve 1340-1341 öğretim yıllarına ait imtihan cetvelleri.

67 Tarsus, 31 Kanunievvel 1341, sayı: 487-288, s. 1. 
öğrenim görmektedir. ỉbtidaî sınıflarını ve rüşdiyenin ilk sınıfını içerisine alan 4 yıllık eğitimin yapıldığı bu tarihte, okulda bir müdür ve 5 öğretmen görev yapmaktadır. Okul binası kira ile tutulmuş olup masrafları öğrencilerden alınan paralarla karşılanmaktadır. Okul bu durumuyla o tarihte Tarsus'ta bulunan en iyi Müslüman okulu durumundadır. ${ }^{68}$ Cumhuriyet yıllarında okulun adı Türk Ocă̆ ilkokulu olarak değiştirilmiştir.

Köylerde Bulunan ibtidaî Mektepler: Tarsus'un nüfus bakımından kalabalık olan Panzinçukuru, Kargılı, Baltalı, Frengülüs, Hacıbozan, Yüksek ve Yenice köylerinde ibtidaî mekteplerin bulunduğu tespit edilmiştir. ${ }^{69}$ Bunlardan Baltalı, Frengülüs, Hacıbozan, Yüksek ve Yenice köylerinde bulunan mektepler Maârif Komisyonu Reisi Yakub Efendi'nin gayreti ve ahalinin de yardımıyla tesis edilmiş ve 21 Eylül 1901 tarihinde hizmete açılmıştır. Bu köylerde önceden var olan ve eski usûle göre eğitim yapan sıbyan mektepleri tamir edilerek usûl-i cedîdeye tebdil edilmiş ve birer mekteb-i ibtidaî hâline dönüştürülmüştür. Muallim olarak da 20 Ekim 1921 tarihinde; Baltalı köyü mektebine Konya Darülmuallimîn'i mezunu Mesud Efendi, Frengülüs köyü mektebine Adana Darü'l Muallimîn'i mezunu Abdullah Efendi, Yüksek köyü mektebine Osman Efendi, Hacıbozan köyü mektebine Hafız Ali Efendi ve Yenice köyü mektebine de Mecid Efendi tayin edilmiştir. Darülmuallimîn mezunu olmayan Osman Efendi, Hafız Ali Efendi ve Mecid Efendilerin usûl-i cedîdeye vâkıf oldukları Maârif Komisyonu tarafından onaylanmıştır. Muallimlerin maaşları 100'er kuruş olup bu miktarın köylüler tarafindan toplanan ve yıllık olarak komisyona teslim edilen meblağdan karşılanması uygun görülmüştür. Bu tarihe Baltalı'da 60, Frengülüs'te 50, Hacıbozan'da 50 ve Yenice'de de 60 öğrencinin bu mekteplere devam ettiği görülmektedir. ${ }^{70}$

\subsection{Rüşdiyeler}

11. Mahmud döneminde, sıbyan mekteplerinin yetersizliği görülünce, bu mekteplerin üst kademesi olarak sınıf-ı sânî denilen okullar açılmıştır. Daha sonra adı padişah tarafından rüşdiye olarak değiştirilen bu okulların idaresi ile meşgul olmak üzere Mekâtib-i Rüşdiye Nezareti kurulmuştur. Rüşdiye okullarının eğitim sistemindeki yeri ise 1845 yılında toplanan Muvakkat Maârif Meclisi ile belirlenmiştir. Buna göre rüşdiye okulları, sıbyan mekteplerinin üstünde ve darülfünûna öğrenci veren bir okul olarak kabul edilmiştir. ${ }^{71} 1859$ 'dan

\footnotetext{
${ }^{68}$ Ahmed Şerif, Anadolu'da Tanin (Birinci Gezi), (Haz. Çetin Börekçi), ìstanbul 1977, s. 177.

${ }^{69}$ Maârif Salnâmesi, 1321, s. 331.

${ }^{70}$ BOA. MF.MKT. 600/34; BOA. MF.MKT. 617/13.

${ }^{71}$ Kodaman, Abdülhamid Devri Eğitim Sistemi, s. 91, 92.
} 
itibaren ülkede kız rüşdiyeleri de açılmaya başlanmıştır. ${ }^{72} 1869$ Maârif-i Umûmiye Nizamnâmesi ile nüfusu 500'den fazla olan her kasabada bir rüşdiye açılması, öğrenci adedine göre bir veya iki öğretmen tayin edilmesi, öğretim süresinin 4 yıl olması, rüşdiyeyi bitirenlerin imtihanla idâdiye kabul edilmesi hususları kabul edilmiştir. Ayrıca 1867 yılında gayrimüslim çocuklarının da rüşdiyelerde eğitim görebilmelerinin yolu açılmıştır. ${ }^{73}$

Kuruluşundan beri müstakil bir eğitim kurumu olarak varlı̆̆ını devam ettiren rüşdiyelerin, 1869 Nizamnâmesi ile yeni açılacak olan ve 3 yıl eğitim verecek olan idadîlerle birleştirilmesi öngörülmüştür. Böylece vilâyet merkezlerinde $7 \mathrm{yll}$, sancak merkezlerinde de 5 yıl eğitim veren ve bünyesinde rüşdî sınıflar bulunan idadîler açılmaya başlanmış ve 1882'den sonra sayıları da bir hayli artmıştır. 1913 yılında çıkarılan Tedrîsat-ı ibtidaiye Kanun-ı Muvakkati ile rüşdiyeler bu sefer ibtidaî mekteplerle birleştirilmiş ve ibtidâ̂ programlı rüşdiye statüsü ile 6 yıllık eğitim veren okullar açılmaya başlanmıştır. ${ }^{74}$ Dolayısıyla 1913 yılından sonra Osmanlı eğitim sisteminde müstakil rüşdiyeler istisnalar dışında kaldırılmış ancak idadîler ve ibtidaîler bünyesinde fiili olarak varıklarını devam ettirmişlerdir.

Tarsus Rüşdiyesi: Tarsus Müftüsü Ahmed Hilmi Efendi'nin müştemilâtıyla birlikte mektep olarak vakfettiği binanın rüşdiye mektebi olması yönünde, Tarsus Sancağı İdare Meclisi'nin kararı üzerine yapılan müracaat neticesinde, 1863 yılında Tarsus Rüşdiyesi açılmıştır. Maârif Nezareti tarafından da okula 600 kuruş maaşla bir muallim-i evvel, 300 kuruş maaşla bir muallim-i sâni ve 100 kuruş maaşla da bir bevvab tayin edilmesi uygun görülmüştür. ${ }^{75} 1863$ yılında eğitim-eğitim öğretime başlayan Tarsus Rüşdiyesi, 1914 yılına kadar hizmetine kesintisiz devam etmiş ve bu tarihte adı Rehber-i Füyûz Mektebi olarak değiştirilerek ibtidaî programlı rüşdiye statüsüne geçirilmiştir.

Tarsus Rüşdiyesi'nde Maârif-i Umûmiye Nizamnâmesi gereğince 4 yılllk eğitim programı uygulamakta, ayrıca bir de mülâzimîn sınıfı bulunmaktadır. Öğrenciler bu sınıfa genellikle 10 yaşında alınmakla birlikte 9 ve 11 yaşlarındaki çocukların kaydedildiği de görülmektedir. Mülâzımîn sınıfı 1888-1889 öğretim yılında kaldırılmış, 1897-1898 öğretim yılında tekrar getirilmiştir. ${ }^{76}$ Bu tarihte

\footnotetext{
${ }^{72}$ Akyüz, Türk Eğitim Tarihi, s. 165.

${ }^{73}$ Mahmud Cevad, Maârif-i Umumiye Nezâreti... ss. 91-99.

${ }^{74}$ Akyüz, Türk Eğitim Tarihi, s. 166, 232, 273.

${ }^{75}$ BOA. MVL. 650/38.

${ }^{76}$ TSIOA, Tarsus Rüşdiyesi'nin 1305 ve 1314 yıllarına ait sene sonu imtihan cetvelleri.
} 
okulun eğitim süresi 4 yıldan 3 yıla düşürülmüştür. 1900-1901 öğretim yılında ise mülâzımîn sınıfı tekrar kaldırılmış, eğitim süresi ise 3 yıl olarak bırakılmıştır. ${ }^{77}$

Rüşdiyede muallim-i evvel, muallim-i sânî ve hat muallimi kadrolarında vazifeli üç öğretmen ve bir de hademe görev yapmaktadır. Okulun öğrenci sayısı ise yıllara göre 60 ile 130 arasında değişkenlik göstermiştir. Birinci sınıfta okuyan öğrenci sayısının genellikle kalabalık olduğu, ancak bu sayının dördüncü sınıfa doğru giderek azaldığı görülmektedir. Örneğin; 1877-1878 öğretim yılında birinci sınıfta 35 öğrenci bulunurken bu öğrencilerin sayısının ikinci sınıfta 19, üçüncü sinıfta 7 ve dördüncü sinıfta da 6 kişiye düştügü tespit edilmiştir. ${ }^{78}$ Yine 18941895 öğretim yılında birinci sınıfa başlayan 23 öğrencinin sayısının ikinci sınıfta 12, üçüncü sınıfta 9 ve dördüncü sınıfta da 8 kişiye kadar düştüğü görülmektedir. ${ }^{79} \mathrm{Bu}$ durumda rüşdiye eğitimine başlayan öğrencilerin pek azının okulu bitirmeye muvaffak olduğu söylenebilir. Incelenen sene sonu imtihanlarını hâvî cetvellerden başarısızlı̆̆ nedeniyle ya da imtihana girmediği için sınıfta kalan öğrencilerin fazlalığı dikkati çekmektedir. Özellikle 1. sınıfa başlayan öğrencilerin bazı yıllar, yarısından fazlasının bir üst sınıfa geçemedikleri görülmektedir. Örneğin; 1876-1877 öğretim yılında rüşdiyeye başlayan 35 birinci sınıf öğrencisinden 4'ü geçer not alamadıkları için, 18 'i de imtihana girmediği için sınıfta kalmıştır. Bu durumda bir üst sınıfa geçen öğrenci sayısı sadece 13 kişidir. ${ }^{80}$ Aynı şekilde 1888-1889 öğretim yılında 1. sınıfa başlayan 40 öğrenciden sadece 18 'i 2 . sınıfa geçebilmiştir. Geriye kalan 22 kişiden 4'ü başarısız oldukları, 14'ü de imtihana girmedikleri için sınıfta kalmışlardır. ${ }^{81}$ Üst sınıflarda ise öğrenci sayılarında azalma görülmekle birlikte 1. sınıflara oranla oldukça azdır.

Tablo 3: Adana Vilâyet ve Maârif Salnamelerine göre Tarsus Rüşdiyesi personeli ve öğrenci sayıları

\begin{tabular}{|c|l|l|c|l|c|}
\hline Sene & Muallim-i Evvel & Muallim-i Sânî & Hat Muallimi & Bevvab & Ö.Sy. \\
\hline 1876 & Hafız Ahmed Efendi & Mustafa Efendi & --- & Ahmed Efendi & 80 \\
\hline 1877 & Hafız Ahmed Efendi & Bülbül Efendi & --- & Ahmed Efendi & 80 \\
\hline 1879 & Hafız Ahmed Efendi & i̇shak Efendi & --- & Ahmed Efendi & --- \\
\hline
\end{tabular}

77 TSIOA, Tarsus Rüşdiyesi'nin 1317 yılına ait sene sonu imtihan cetveli.

${ }^{78}$ TSiOA, Tarsus Rüşdiyesi'nin 1293, 1294, 1295 ve 1296 yıllarına ait sene sonu imtihan cetvelleri.

79 TSiOA, Tarsus Rüşdiyesi'nin 1310, 1311, 1312 ve 1313 yıllarına ait sene sonu imtihan cetvelleri.

80 TSIOA, Tarsus Rüşdiyesi'nin 1293 yılına ait sene sonu imtihan cetveli.

${ }^{81}$ TSIOA, Tarsus Rüşdiyesi'nin 1305 yılına ait sene sonu imtihan cetveli. 


\begin{tabular}{|c|l|l|c|c|c|}
\hline 1881 & Hafiz Ahmed Efendi & ishak Efendi & -- & Ahmed Ağa & 93 \\
\hline 1890 & Hafiz Ahmed Efendi & Hüseyin Efendi & --- & ibrahim Efendi & --- \\
\hline 1891 & Hafız Ahmed Efendi & Hüseyin Efendi & -- & íbrahim Efendi & --- \\
\hline 1894 & Hafız Ahmed Efendi & Hüseyin Efendi & --- & ibrahim Efendi & 65 \\
\hline 1898 & Hacı Ahmed Efendi & Hüseyin Efendi & Rıfat Efendi & --- & 86 \\
\hline 1899 & Hacı Ahmed Efendi & Hüseyin Efendi & Rıfat Efendi & --- & 94 \\
\hline 1900 & Şevket Efendi & Hüseyin Efendi & Rıfat Efendi & --- & 98 \\
\hline 1901 & Şevket Efendi & Hüseyin Efendi & Rıfat Efendi & --- & 98 \\
\hline 1902 & Şevket Efendi & Hüseyin Efendi & & İsmail Efendi & 105 \\
\hline 1903 & Şevket Efendi & Hüseyin Efendi & Rıfat Efendi & -- & 130 \\
\hline
\end{tabular}

Tarsus Rüşdiyesi'nin açılmasından sonra karşılaşılan en önemli sorunlardan birisi rüşdiye okullarının çalışma takviminin Çukurova dâhilindeki okullarda uygulanmasının zorluğu olmuştur. Çünkü bölge halkının yaz ayları yaklaşınca yaylalara gitmesi nedeniyle rüşdiyelerdeki öğrenci sayıları bir hayli azaltmakta, bu da öğrencilerin genellikle 15 Haziran ile 15 Temmuz arasında yapılan umûmî imtihanlara katılamamalarına neden olmaktadır. Bu nedenle Tarsus Rüşdiyesi idaresi, imtihanların daha erken bir tarihte yapılması yönünde 1872 yılında müracaatta bulunmuştur. Ancak bu durum nizama aykırı olduğu gerekçesiyle kabul görmemiş, imtihanların mümkün olduğunca haziran ayı içerisinde yapılması istenmiştir. ${ }^{82}$ Bunun üzerine rüşdiye personeli çözümü okulu yaylaya taşımakta bulmuştur. Yaylada kiralanan çadırda eğitim öğretime devam edilmiş, masraflar da ahali tarafından karşılanmıștır. ${ }^{83}$ ilerleyen yıllarda Tarsus'un da içerisinde bulunduğu Çukurova bölgesi rüşdiyelerinde sene sonu umûmî imtihanlarının haziran başında yapılarak okulun bir müddet erken tatil edilmesinin yolu açılmıştır. ${ }^{84}$ Ancak bu da sorunun çözümü için yeterli olmamışır. Çünkü Tarsus Rüşdiyesi'nin imtihan cetvellerinden, I. Sınıf öğrencilerinin genellikle yarıya yakınının haziran ayında yapılan sene sonu imtihanlarına girmediği için sınıfta kaldığı görülmektedir. Örneğin; 1873-1874

${ }^{82}$ BOA. MF.MKT. $1 / 41$.

${ }^{83}$ BOA. MF.MKT. 2/138.

${ }^{84}$ BOA. MF.MKT. 275/71. 
öğretim yılında 1. sınıfta okuyan 28 öğrenciden 10'u, 1876-1877 öğretim yılında 35 öğrenciden 18'i, 1888-1889 öğretim yılında 40 öğrenciden 14'ü ve 1893-1894 öğretim yılında 22 öğrenciden 10'u bu imtihanlara girmemiştir. ${ }^{85}$ Bunların haziran ayından önce aileleriyle birlikte yaylalara giden öğrenciler olduğu ilk akla gelen ihtimaldir.

Tarsus Müftüsü Ahmed Hilmi Efendi'nin vakfettiği ilk rüşdiye binası zamanla ihtiyaca cevap veremez hâle gelmiştir. Binanın oldukça eski ve kullanışsız olması, ayrıca öğrenci sağlı̆̆ı açısından da uygun olmaması nedeniyle tamirine ihtiyaç olduğuna dair ilk yazışmalar 1907 yılında yapılmaya başlanmıştır. ${ }^{86} 15$ Şubat 1908 tarihinde Adana Maârif Müdürü ìsmail imzasıyla Maârif Nezareti'ne gönderilen bir yazıda rüşdiye mektebi için Tarsus'ta yeni ve güzel bir binanın vilâyet erkânının da katılmış olduğu görkemli bir törenle hizmete açıldığı belirtilmektedir. ${ }^{87}$ Ancak bu açılışın üzerinden fazla bir zaman geçmeden Adana Maârif Müdürlüğü, Tarsus Rüşdiyesi'nin binasının oldukça harap olduğu, sadece bir oda ve bir bahçeden ibaret bulunduğu ve ihtiyaca cevap veremediği için 200 liraya satılarak Tarsus Belediyesi tarafindan tahsis edilen ve şehrin kuzey doğusunda bulunan arsa üzerine 1.000 lira masrafla yeni bir rüşdiye binasınının yapılması yönünde Maârif Vekâleti'ne müracaatta bulunmuştur. Burada yeni yapılan ve henüz açılalı beş ay gibi kısa bir zaman olan Tarsus Rüşdiyesi binası için böyle bir isteğin yapılması ilginçtir. Yapılan tahkikat neticesinde Maârif Vekâleti bu isteği yerinde bulmamıştır. Gerekçe olarak da binanın söylenildiği gibi bir odadan ibaret olmayıp beş odasının bulunduğu, eğer 15-20 bin kuruşa tamir edilirse ihtiyaca cevap verebilecek düzeye gelebileceği, üstelik yeni okul binası için gösterilen yerin de şehrin dışında olduğu ve öğrenciler için okula gidiş-gelişlerinin zor olacağı belirtilmiştir. Ancak bu yazışmalar yapılmadan evvel belirtilen yere temel atılarak inşaatın başlandığı görülmektedir. Bunun üzerine Maârif Vekâleti, mevcut okulun yerinin çarşının en değerli mevkisinde olmasından dolayı kesinlikle satılmaması istenmiştir $^{88}$ Ancak eski Rüşdiye binasının 1909 yılında 400 lira bedel karşıllğında İstanbul'dan talip olan birisine satılması kararlaştırılmıştır. ${ }^{89}$

Tarsus Rüşdiyesi'nin pek de iç açıcı olmayan fiziki durumu ile ilgili 1910 yılı başlarında Tarsus'ta bulunan Ahmed Şerif ise şunları nakletmektedir:

\footnotetext{
85 TSIOA, Tarsus Rüşdiyesi'nin 1290, 1293, 1305 ve 1310 yıllarına ait sene sonu imtihan cetvelleri.

${ }^{86}$ BOA. MF.MKT. 1033/75.

${ }^{87}$ BOA. MF.MKT. 1041/27.

${ }^{88}$ BOA. DH.MKT. 1300/16.

${ }^{89}$ BOA. DH.MKT. 2728/52.
} 
“...Maârif Tarsus'ta pek ruhsuz, âdeta hiç denilebilecek bir hâldedir. Rüşdiye mektebi diye götürüldügüum yer bir okul binasından başka her şeydir. Perşembe olduğu için çocukları erken salıvermişler ise de öğrencinin miktarının altmışa yakın olduğunu ögrendim. Okulda oturacak sıralar bile yoktu. Burada görülen pisliğe, düzensizliğe göre öğretmenlerin, öğrencilerin durumunu düşündüm. Kırk elli kadar çocuğun doldurulduğu havasız bir yer... ${ }^{\prime 0}$

Bu ifadelerin o tarihte Tarsus Rüşdiyesi'nin içerisinde bulunduğu durumu en iyi şekilde ifade ettiği söylenebilir.

1869 Vilâyet Nizamnâmesi gereğince sancak merkezlerinde 4 yıllık rüşdiye okullarının üstünde, öğretim süresi 3 yıl olan idadîler açılmıştır. Tarsus, ülkenin en büyük kazalarından birisi olmasına rağmen kaza statüsünde olduğu için nizamnâme gereği idadîsi olmayıp şehirdeki en yüksek dereceli Müslüman okulu Tarsus Rüşdiyesi'dir. Bu durum, Tarsus'ta gerek Amerikan Protestanlarına, gerekse de Katolik misyonerlerine ait daha kaliteli eğitim veren okulların bulunması nedeniyle, Müslüman ahalinin eğitim alanında gayrimüslimlere nazaran zayıf kalmasına neden olmuştur. Bu nedenle kuruluş amacı belli olan bu okulların halk üzerindeki tesirlerinin azaltılması ve Tarsus'un eğitim seviyesinin arttırılması amacıyla 1908 yılında Tarsus Rüşdiyesi'nin idadî seviyesine yükseltilmesi teklif edilmiştir. ${ }^{91}$ Ancak bu girişim netice vermemiş, Tarsus'ta lise seviyesinde okulun açılması Cumhuriyet yıllarına kalmıştır.

Tarsus İnas Rüşdiyesi: Tarsus'ta kızlar için rüşdiye mektebi açma girişimleri misyonerlerin faaliyetlerine karşı bir tedbir amacıyla başlamıştır. Özellikle Amerikan misyonerlerinin Tarsus'ta kalabalık bir nüfusa sahip olan Nusayrî Araplar üzerinde etkili olmaya çalıştıkları bilinmektedir. Müslüman kızların eğitimi için ibtidaî mekteplerin üstünde herhangi bir eğitim kurumunun bulunmamasının, misyonerlerin işine geldiği fark edilmiştir. Amerikalı misyoner Doktor Metheny tarafından küçük yaştaki Nusayrî kızlarının yatılı olarak Mersin'deki misyoner okuluna alınması ve bir kısmının Amerika'ya kaçırılması, yetkilileri bu konuda tedbir almaya sevk etmiştir. Öncelikle kız çocuklarının eğitiminde görülen boşluğun doldurulması kanaati hâsıl olmuştur. Bu amaçla Tarsus'ta bir inas rüşdiyesi açllması fikri ilk olarak 1891 yılında gündeme gelmiştir. ${ }^{92} 1893$ yılında ise Mersin ve Tarsus'ta birer İnas Rüşdiyesi ve kızlar için yatılı idadî açılmasına karar verilmiştir. ${ }^{93}$ Bir müddet sonra Tarsus'ta İnas

${ }^{90}$ Ahmed Şerif, Anadolu'da Tanin, s. 176.

${ }^{91} B O A$, Y.MTV. 306/83.

${ }^{92}$ BOA. BEO. 325/24341.

${ }^{93}$ BOA. MF.MKT. 195/10. 
Rüştiyesi açılmış ancak idadî hususunda herhangi bir gelişme olmamışır. Tarsus İnas Rüşdiyesi'nde muallime olarak 1901-1907 yılları arasında Zeynep Hikmet Hanım vazife yapmıştır. ${ }^{94}$

Panzinçukuru Rüşdiyesi: Gülek nahiyesinin merkezi olan Panzinçukuru, Tarsus'a bağlı en büyük köylerden biridir. Buradaki rüşdiye mektebinin ne zaman açıldığı kesin olarak bilinmemekle birlikte mevcut en eski kayıtlar 1892 yılına aittir. ${ }^{95} 1893$ yllında Hasan Nazmi Efendi muallim-i evvel olarak tayin edilmiştir. $^{96} 1898$ yılında 72 öğrencinin eğitim gördüğü okulda, bu tarihte muallim-i evvel olarak Mehmed Nuri Efendi görev yapmakta olup muallim-i sâni kadrosu ise münhal durumdadır. ${ }^{97} 1899$ yılında yine aynı muallimin nezaretinde okulda 68 öğrencinin eğitim gördüğü tespit edilmiştir. ${ }^{98} 1900$ yılında ise muallim değişmiş Abdülkerim Efendi göreve başlamıştır. Aslında hat muallimi olan Abdülkerim Efendi bu tarihte muallim-i evvellik vazifesini vekâleten yürütmektedir. ${ }^{99}$

Panzinçukuru Mekteb-i Rüşdiyesi'nin 1898 yılında lağvedilerek tahsisatının Mersin İnas Rüşdiyesine aktarılması istenmiştir. ${ }^{100}$ Bu tarihte 72 öğrencinin eğitim gördüğü okul lağvedilmemiş ancak tam rüşdiye statüsünden nim (yarım) rüşdiye statüsüne düşürülmüştür. 400 kuruş olan öğretmen maaşı ise 200 kuruşa indirilmiştir. Bu nedenle muallim Abdülkerim Efendi, 1905 yılında Maârif Nezareti'ne başvurarak maaşının uzun süredir ödenmediğini, ödense bile bu miktarla geçinmesinin zor olduğunu, çoluk çocuğunun perişan olduğunu belirtmiş ve ya maaşının muntazaman ödenmesini ya da okulun kapatılmasını istemiştir. $\mathrm{Bu}$ müracaat neticesinde Abdülkerim Efendi'nin maaşının muntazaman ödenmesi ve mağdur edilmemesi yönünde talimat verilmiş ve bu hususta Mersin Mutasarrıflı̆̆'ndan taahhüt alınmıştır. ${ }^{101}$

\section{Gayrimüslimlere Ait Okullar}

\subsection{Azınlık Okulları}

Osmanlı Devleti, tabiiyeti altında yaşayan azınlıkların kendi cemaatlerinin eğitim işlerini üstlenmelerine müsaade etmiştir. Osmanlı ülkesinde yaşayan

${ }^{94}$ BOA. MF.MKT. 1026/36

${ }^{95}$ BOA. MF.MKT. 279/52.

${ }^{96}$ BOA. MF.MKT. 189/111.

${ }^{97}$ Maârif Salnâmesi, 1316, s. 832.

${ }^{98}$ Maârif Salnâmesi, 1317, s. 930.

${ }^{99}$ Maârif Salnâmesi, 1318, s. 1033.

${ }^{100}$ BOA. MF.MKT. 396/47.

${ }^{101}$ BOA. MF.MKT. 939/48. 
Ermeni ve Rumlar kendi kiliselerinin bünyesinde kendi okullarına sahip olmuşlardır. Aynı şekilde Yahudiler ve diğer azınlık gruplar da kurdukları okullarında çocuklarına kendileri eğitim vermişlerdir. ${ }^{102}$

Azınlık okulları, Tanzimat döneminde kendilerine tanınan imkânların etkisiyle büyük bir gelişme göstermiştir. Tanzimat'tan sonra da gelişme imkânı bulan bu okullar, asıl büyüme ivmesini, Il. Meşrutiyet'in başında görülen serbestlik yıllarında kazanmıştır. Bu dönemden sonra ülkenin her tarafına yayılan azınlık okullarının, İtilâf Devletlerinin çıkarlarına hizmet eden, çetelerin yuvalandığı yerler hâline geldiği görülmektedir. ${ }^{103}$ Özellikle Rum ve Ermenilere ait okullar ve bu okullarda vazifeli öğretmenler, Türkiye'yi parçalama hedefi doğrultusunda, gerekli altyapıyı hazırlamak için Millî Mücadele yıllarında da faaliyetlerine ara vermeden devam etmiş̧lerdir. Kurtuluş Savaşı'ndan sonra ülkedeki Ermeni nüfusunun, mübadeleden sonra da Rum nüfusunun iyice azalması neticesinde, çoğunluğu teşkil eden bu iki millete ait okulların birçoğu kapanmış, mevcutlar ise Tevhid-i Tedrîsat Kanunu ile Millî Eğitim Bakanlığı'na bağlanmıştır.

Tanzimat sonrası dönemde Tarsus'ta yaşayan azınlıklardan Ermeniler, Rumlar ve Marunîlere ait okulların mevcudiyeti hakkında belgeler bulunmaktadır. Ancak bu okulların sayısı hakkında muhtelif bilgiler mevcuttur. 1881, 1890, 1891, 1901 ve 1902 yılı Adana Vilâyet Salnâmelerinde Tarsus'ta 10 adet azınlık mektebinin bulunduğu kayıtlıdır. ${ }^{104}$ Cuinet ise şehirde 2'si erkek ve ı'i kız okulu olmak üzere 3 Rum, 2 Ermeni, 1 Katolik ve 1 de Protestan okulunun bulunduğunu belirtmektedir. ${ }^{105} 1905$ yılı Şark Ticaret Yıllıklarında şehirde Gregoryen Ermeni Mektebi (erkek), Katolik Ermeni Mektebi (karışı), Katolik Rum Mektebi (erkek) ve Ortodoks Rum Mektebi (karışık) olmak üzere toplam 4 adet azınlık okulunun bulunduğu belirtilmektedir. ${ }^{106}$

1896 yılına ait bir belgede üç yıl önce Fransız Konsolosluğu tarafindan Tarsus'ta bulunan Marunî Mektebi'ne 7 adet coğrafya atlası gönderildiğinden bahsedilmektedir. Bu atlasların zararlı neşriyattan olması nedeniyle ülkeye girişlerinin engellenmesi istenmektedir. ${ }^{107} \mathrm{Bu}$ belgeden $1890^{\prime} l_{1}$ yıllarda, muhtemelen Tarsus'ta mevcut Marunî Kilisesi bünyesinde, bir de mektebin

\footnotetext{
${ }^{102}$ Akyüz, Türk Eğitim Tarihi, s. 103, 104.

${ }^{103}$ Akyüz, Türk Eğitim Tarihi, s. 277.

${ }^{104} A V S, 1299$, s. 42; $A V S$, 1308, s. 98; $A V S$, 1309, s. 105; $A V S$, 1319, s. 189.

${ }^{105}$ Cuinet, La Turquie d'Asie, $11,11$.

${ }^{106}$ Annuaire Oriental du Commerce, 1905, s. 1628.

${ }^{107}$ BOA. MF.MKT. 304/5.
} 
bulunduğu anlaşılmaktadır. Ancak bu okulun öğrenci sayısı ve ne zamana kadar varlığını devam ettirdiği hususunda herhangi bir bilgi mevcut değildir.

Bu verilerden Tarsus'ta Ermeni ve Rumların mensup oldukları mezheplere göre bağlı bulundukları kiliselerin her birinin bünyesinde o cemaatin okullarının bulunduğu anlaşılmaktadır. Bu doğrultuda 1879 yılında Tarsus'a gelen E. J. Davis, şehirde Rum, Ermeni ve Suriye Hristiyanlarının okullarının bağlı bulundukları kiliselerin bünyesinde bulunduğunu belirtmektedir. ${ }^{108} 1913$ yılında Protestan cemaatine mahsus üstü kilise, altı okul olmak üzere planlanan bir binanın inşası için ruhsat istenmiş ve 4 Ekim 1913 tarihinde istenen ruhsat Şûra-yı Devlet'ten çıkmıştır. ${ }^{109} \mathrm{Bu}$ vesika son dönemlerde de azınlık okullarının kiliselerin bünyesinde planlandığını göstermesi açısından önemlidir.

\subsection{Yabancı Okullar}

Osmanlı ülkesindeki yabancı okulların geçmişi çok eskiye dayanmaktadır. Şüphesiz bu okulları misyonerlik faaliyetlerinin Osmanlı ülkesindeki gelişimi ile aynı paralelde düşünmek gerekir. ilk açılan yabancı okullar XVl. yüzyılın sonlarında Fransa kralının himayesinde faaliyet gösteren Katolik okullarıdır. ${ }^{10}$ Katoliklerden sonra Protestanlar Osmanlı ülkesinde yoğun bir misyonerlik faaliyetine başlamışlardır. Özellikle Amerikalılar açtıkları okul, hastane ve yetimhanelerle Osmanlı topraklarındaki en etkili misyoner grubu olmuşlardır."'

Hristiyan âleminin en tanınmış misyoneri olarak kabul edilen Aziz Paulus'un" ${ }^{12}$ yaşadığı yer olması nedeniyle Hristiyanlar için önemli bir merkez konumunda olan Tarsus'ta misyonerlik faaliyetlerinin, XIX. yüzyılın ikinci yarısından sonra hız kazandığı görülmektedir. Fransızların Cizvit, Amerikalıların Protestan misyonerleri, öncelikle Tarsus'un gayrimüslim nüfusunun fazla olduğu köylerinde ve mahallelerinde ev kiralamak suretiyle eğitim faaliyetlerine başlamışlardır. 1887 yılında misyonerlerin evlerde Müslüman ve Hristiyan çocuklarına eğitim verdiklerinin anlaşılması üzerine, ruhsatsız olarak faaliyet gösteren bu okullar kapatılmak yerine, yöneticilerinden Maârif Nezareti nizamnâmesi ahkâmına uygun hâle getirilmesi istenmiştir." ${ }^{13}$ Şüphesiz devletin,

\footnotetext{
${ }^{108}$ Edwin John Davis, Life In Asiatic Turkey, London 1879, s. 33.

${ }^{109}$ BOA. i. AZN. 114/1331 Za-18.

${ }^{10}$ M. Hidayet Vahapoğlu, Osmanlı'dan Günümüze Azınlık ve Yabancı Okullar, ìstanbul 1992, s. 27, 28; Ayten Sezer, Atatürk Döneminde Yabancı Okullar (1923-1938), Ankara 1999, s. 7.

I'" Uygur Kocabaşoğlu, “Amerikan Okulları", Tanzimat'tan Cumhuriyet'e Türkiye Ansiklopedisi, istanbul 1985, Il, 496.

112 Vahapoğlu, Osmanlı'dan Günümüze Azınlık ve Yabancı Okullar, s. 25.

${ }^{113}$ BOA. DH.MKT. 1408/68.
} 
misyonerlerin faaliyetlerine karşı takındığı bu yumuşak tavır ve serbest çalışma ortamı, ilerleyen yıllarda Tarsus'un, Amerika'nın en eski ve en güçlü misyonerlik örgütü olan American Board of Commissioners for Foreign Missions (ABCFM)'nin önemli misyon merkezlerinden birisi hâline gelmesinde etkili olmuştur. Amerikalı misyonerlerin Tarsus'taki merkezleri St. Paul's Institute adıyla 1888 yılında açılan ve günümüzde de Tarsus Amerikan Koleji olarak eğitim-öğretime devam eden okuldur.

St. Paul Enstitüsü (Tarsus Amerikan Koleji): Amerikalılar, özellikle Ermeni nüfusunun yoğun olduğu yerleri misyon merkezi olarak belirlemiş̧ler, buralarda her dereceden okullar açarak kendilerine hedef kitle olarak belirledikleri Ermeni gençleri ve aileleri üzerinde etkili olmayı amaçlamışlardır. ${ }^{114} \mathrm{Bu}$ doğrultuda ilk misyonun, 1820 yılında İzmir'de kurulmasından sonra ilk Amerikan okulu da 1831 yılında İstanbul'da açılmıştır. Bu tarihten sonra ilerleyen yıllarda Trabzon, Erzurum, Antep, Sivas, Adana, Merzifon, Diyarbakır, Kayseri ve Harput misyonları açılmıştır. 1870 yılına gelindiğinde ise bugünkü Türkiye sınırları içerisinde kalan tüm alanların Amerikan misyoner faaliyetlerinin etki alanı içerisine girdiğini söylemek mümkündür. ${ }^{115}$

American Board teşkilâtının Orta Anadolu misyon bölgesi içerisinde yer alan ve bünyesinde bir miktar Ermeni nüfus barındıran Tarsus'ta, bir Amerikan misyoner okulu açma fikri, diğer bölgelerde olduğu gibi ne halktan ne de Board teşkilâtından gelen bir talep doğrultusunda olmuştur." Tarsus'ta yaşayan Ermeni nüfusunun oldukça azınlıkta olması (\%4-5) Board teşkilâtının ilk başta ilgisinin buraya yönelmemesinin en önemli nedeni olmalıdır.

Tarsus'taki Amerikan Okulu, St. Paul Enstitüsü adılla New York'lu iş adamı Elliott Fitch Shepard'ın girişimleri sonucu kurulmuştur. 1885 yılında hacı olmak için Kudüs'e giderken, Aziz Paulus'un doğduğu yer olan Tarsus'a uğrayan Shepart, bu kasabayı çok beğenmiş ve burada bir okul açmayı düşünmüştür. Amerika'daki Presbiteryen Board (BFMBC) tarafindan desteklenen Shepart'in çalışmaları sonucunda öncelikle St. Paul Cemiyeti ${ }^{117}$ adıyla bir cemiyet kurulmuş ve bir mütevelli heyeti oluşturulmuştur. Ardından da bu cemiyetin bünyesinde yer alacak okulun kuruluş sözleşmesi, 1887 yılında New York Senatosu tarafından onaylanmıştır. 14 Kasım 1888 tarihinde Amerika'dan Hariciye

\footnotetext{
114 ilknur Polat, "Osmanlı İmparatorluğu'nda Açılan Amerikan Okulları Üzerinde Bir İnceleme", Belleten, Lll (203), s. 634; Özgür Yıldız, Misyonerlik ve Amerikan Board Teşkilât, İstanbul 2009, s. 53.

${ }^{115}$ Kocabaşoğlu, Anadolu'daki Amerika, s. 106.

${ }^{116}$ Kocabaşoğlu, Anadolu'daki Amerika, s. 200.

117 BOA. HR.TO. 148/84.
} 
Nezareti'ne gelen bir takrirde; Tarsus'ta New York Eyaleti kanunlarına tâbi St. Paul adlı bir cemiyet kurulduğu belirtildikten sonra, cemiyetin maksadının insaniyete hizmet etmek olduğu vurgulanmıştır. Cemiyet üyelerinin bu amaç doğrultusunda Tarsus ve havalisinde çocuk ve yetimlerin iâşe, talim ve terbiyesi için çalışacakları, bunun için şimdilik 140 çocuk ve yetimin ihtiyacını karşılayacak meblağın tahsis edildiği belirtilmiştir. Ayrıca bu cemiyeti kuranların, Amerikan Dışişleri Bakanlığı'na bir lâyiha vererek, Tarsus'ta menkûl ve gayr-i menkûl emlâk alma, satma, kiralama ve kullanma, muallim yetiştirme, özellikle ihtiyacı olan kız ve erkek öğrencilerin iâşesini karşılama ve bunların eğitimini üstlenme, kitap ve gazete çıkarma gibi faaliyetlerde bulunabilmeyi talep ettikleri de belirtilmektedir. Ardından da insaniyet namına hizmet verecek olan bu cemiyetin faaliyetleri ve açılması düşünülen okul için bir an evvel irade-i seniyye çıkması yönünde Hariciye Nezareti'nden yardım istenmektedir. ${ }^{.8}$ Hariciye Nezâreti'nin, cemiyetin Tarsus'ta açacağı okul hakkında daha fazla malûmat istemesi üzerine gelen cevabî yazıda; cemiyetin Tarsus'taki temsilcilerinin öğretmenler Jenanian ve Alexander Lashlan ile teftiş komisyonu azasından Şakmakyan olduğu bildirildikten sonra, okulda Türkçe ve Ermenice hurûf ile sarf-1 Türkî, İngilizce gramer, coğrafya-i tabiî, ulûm-ı riyâziye ve İncil-i Şerif derslerinin okutulacağı, ayrıca ileride çiftçilik ve marangozluk sanatları, Rumca, Ermenice ve Fransızca lisanları, tarih-i umûmî, kavanîn-i ticariye ve düveliye, hikmet-i tabiiye, felsefe ve ulûm-1 tabiye derslerinin de konulabileceği belirtilmiştir. Ayrıca gerekli olan irade-i seniyyenin bir an evvel çıkacağının ümit edildiği tekrar vurgulanmıştır." Ancak beklenilen bu irade çıkmayacak okul ise açılışından ancak 5 yıl sonra Maârif Nezareti'nin verdiği ruhsat ile resmiyet kazanacaktır. ${ }^{120}$

Cemiyet tarafından Tarsus'a gönderilen Jenanian okulun başına getirilmiş, Lashlan ise öğretmen olarak tayin edilmiştir. Okula kurucu müdür olarak bir Amerikalının değil de bir Ermeni'nin tayin edilmesi, şüphesiz misyonerlerin Ermenilerin sempatisini kazanma amacını güttüklerini göstermektedir. Jenanian, aslen Zor Sancağı'ndan olup Türkiye'deki misyoner okullarında eğitim görmüştür. Adana'da Protestan cemaatine vaizlik yaparken yalan yanlış söylemlerde bulunmasından dolayı dönemin Adana Valisi Abidin Paşa tarafindan şehirden kovulmuştur. Bunun üzerine Amerika'ya giden Jenanian, bir süre din eğitimi aldıktan sonra burada evlenmiş ve American Board tarafından 30 bin lira maaş ile okul açmak üzere Tarsus'a gönderilmiştir. ${ }^{121} 1888$ yılı başlarında Tarsus'a gelen Jenanian, hazırlıkları tamamladıktan sonra irade-i seniyye çıkmasını ve

${ }^{118}$ BOA. HR.TO. 148/84.

${ }^{119}$ BOA. HR.TO. 148/101.

${ }^{120}$ BOA. Y.PRK.MF. $4 / 36$.

${ }^{121}$ BOA. i.DH. 1217/95284. 
ruhsat almayı beklemeksizin, 22 Kasım 1888 tarihinde 8 öğrenci ${ }^{122}$ ile St. Paul Enstitüsü'nü açmıştır. Sene sonunda ise öğrenci sayısı 33 kişiye ulaşmıştır. ${ }^{123}$ Öğrencilerin tamamı Ermeni olup kuvvetle muhtemel ki tamamı Protestan ailelerin çocuklarıdır. ${ }^{124}$

Okul açıldıktan sonra Jenanian, Tarsus'taki misyonerlik çalışmalarına hız vermiştir. St. Paul Enstitüsü bünyesinde yürütülen bu faaliyetler neticesinde şehirdeki Protestanların merkezinin Protestan Kilisesi'nden yavaş yavaş Amerikan Okulu'na doğru kaymaya başladığı anlaşılmaktadır. Ancak bu durum, şehirdeki Potestan ruhanî reisi ve vâizi nezdinde hoş karşılanmamıştır. Jenanian'ın Protestan vâiz Agop Efendi'yi şehirden kovdurması huzursuzluğun daha da artmasına neden olmuştur. Bunun üzerine Tarsus Protestan Cemaati Reis-i Ruhanîsi Vekili Minas Cereciyan, Jenanian'in asıl emel ve niyetini daima gizlediğini, amacının mensubu olduğu misyoner şirketini güçlendirmek, ardından da yerel yönetime müdahale ederek karışıklık çıkarmak olduğunu belirtmiş ve bu durumu hükümete şikâyet etmiştir. ${ }^{125}$

1891 yılında Mac Lashlan okuldaki görevinden ayrılarak İzmir'e gitmiş ve burada İnternational Collage'i kurmuştur. Hartune Jenanian ise 1893 yılında belki de yukarıda bahsedilen sebeplerden dolayı okuldan ayrılmış ve yerine bir American Board misyoneri olan Dr. Thomas D. Chiristie atanmıştır. ${ }^{126} \mathrm{Dr}$. Christie geldikten sonra Jenanian, Konya taraflarında açılacak olan 8 adet misyoner okulunun yerlerini tespit etmek için seyyar müfettiş olarak tayin edilmiştir. $^{127}$

Tarsus Amerikan Okulu'nun asıl gelişmesi Dr. Christie'nin 27 yıllık müdürlüğü döneminde olmuştur. Mütevelli heyetinin ve danışma kurulunun kararıla okul, 1893 yılının Kasım ayında American Board (ABCFM)'un

\footnotetext{
${ }^{122}$ Uygur Kocabaşoğlu, Frank Stone'a dayandırarak okulun eğitime 17 öğrenci ve 3 öğretmenle başladığını belirtmektedir. Kocabaşoğlu, Anadolu'daki Amerika, s. 201.

${ }^{123}$ Alan A. Bartholomew, A History of Tarsus American School (1888-1988), Tarsus 1988, s. 12, 13; Brian Johnson, “St. Paul Okulu'ndan Tarsus Amerikan Koleji'ne bir Okulun Dönüşümü, Toplumsal Tarih, Şubat 2006, sayı: 146, s. 33.

${ }^{124}$ Bartholomew, A History of Tarsus American School, s. 13.

${ }^{125}$ BOA. i.DH. 1217/95284.

${ }^{126}$ Bartholomew, A History of Tarsus American School, s. 15; Johnson, "St. Paul Okulu'ndan Tarsus Amerikan Koleji'ne...", s. 33.

${ }^{127}$ BOA. i.DH. 1309/1311 Ca-40.
} 
yönetimine geçmiştir. ${ }^{128} 2$ Aralık 1893 tarihinde de Osmanlı Maârif Nezareti tarafından ruhsatlandırılarak idadî statüsünde yabancı okul olarak tanınmışıır. ${ }^{129}$

Kurulduğu yıllarda kiralık bir binada eğitime başlayan St. Paul Enstitüsü, Dr. Christie döneminde gerek eğitim gerekse de fiziki şartlar açısından hızlı bir gelişme göstermiştir. 1895 yılında Eliot Shepart'ın eşi tarafından yapılan bağışla iki katlı bir bina satın alınmıştır. Bu binanın yanındaki üç dönümlük arsa ise önce kiralanmak suretiyle daha sonra da satın alınarak okula tahsis edilmiştir. Böylece St. Paul Enstitüsü Câmi-i Nûr Mahallesi'nde bugünkü yerine taşınmıştır. Bu yeni bina Eliot Shepart'ın kızının ismine izafeten Marguerite Shepart Hall olarak isimlendirilmiştir. ilerleyen yıllarda ihtiyaçlar doğrultusunda okula yeni binalar eklenmiştir. 1898 yılında Dr. Christie'nin eşi Mrs. Christie'nin kendi parasıyla yaptırdı̆̆ı ve babasının adını verdiği iki katlı Brewer Hall binası hizmete açılmıştır. Bu binanın bir odası ilerleyen yıllarda okulda oldukça etkili olan Young Men's Christian Assaciation/Y.M.C.A. (Genç Hristiyan Erkekler Cemiyeti) için tahsis edilmiştir. 1899 yılında ise Maraş Amerikan Yetimhanesi'nin katkılarıyla yaptırılan iki katlı Maraş Hall hizmete girmiştir. Şehrin en görkemli binası olan Stickler Hall'ın yapımına ise 1905 yılında başlanmışıı. Ancak bu binanın da ruhsatsız olarak inşa edildiği anlaşımaktadır. Dr. Christie hükümetin bu konuda kendisine yaptığı uyarıları dinlemeyerek binanın yapımına devam etmiştir. ${ }^{130}$ ilk olarak 1911 yılında kullanıma açılan binanın tam olarak bitirilebilmesi ise 1. Dünya Savaşı yıllarını bulmuştur..'1 Böylece okul, binaları ve bahçesiyle bir kampus hâline gelmiştir. Ayrıca halkın daha çok yaylalık olarak kullandığı Namrun'da da yazlık bir okul olarak kullanılabilecek bir bina temin edilmiştir. ${ }^{132}$ Namrun'daki bu okulun, çok sıcak olan yaz aylarında öğretmen ve birkısım öğrencilerin eğitime devam ettikleri yazlık bir mekân olduğu anlaşılmaktadır.

Yalnızca erkek öğrencilerin eğitim gördüğü idadî statüsündeki okulun, 1888 yılında 8 kişi olan öğrenci sayısı ilerleyen yıllarda hayli artış göstermiştir. Şüphesiz bunda Protestan misyonerlerinin, Ermeniler başta olmak üzere Hristiyan cemaatler üzerinde yaptıkları propagandanın etkisi büyüktür. Bu çalışmaların semeresi olarak okulda Ermeni çocukları ile birlikte az sayıda da olsa Rum çocuklarının da bulunduğu görülmektedir. Okul sadece Tarsus'tan değil Adana, Maraş, Antep gibi çevre vilâyetler ile bunlara bağlı kaza ve

${ }^{128}$ Kocabaşoğlu, Anadolu'daki Amerika, s. 201.

${ }^{129}$ Maârif Salnâmesi, 1318, s. 1044, 1045.

${ }^{130}$ BOA. DH.MKT. $1131 / 82$.

${ }^{131}$ Bartholomew, A History of Tarsus American School, s. 20, 21; Johnson, "St. Paul Okulu'ndan

Tarsus Amerikan Koleji'ne...”, s. 34.

${ }^{132}$ BOA. Y.A.HUS. 335/67; BOA. DH.MKT. 2073/2. 
köylerden de öğrenci kabul etmektedir. Örneğin 1895-1896 ders yılında okulda 7 ögretmen ve 30 farklı yerleşim biriminden gelen $65^{\prime}$ i Ermeni, 14'ü Rum ve l'i de Amerikalı olmak üzere toplam 80 öğrencinin bulunduğu görülmektedir. 1897 yılında 11 öğretmenin görev yaptı̆̆ 1 okulda, 7 vilâyetten 134 öğrenci bulunmaktadır. Bu öğrencilerden 95'i yatılıdır. Toplam öğrencinin \%16'sını Rumlar oluşturmaktadır. ${ }^{133}$ Maârif Salnâmelerinde ise 1898 ile 1901 yılları arasında okulda 92 yatılı öğrencinin öğrenim gördüğü kayıtlıdır. ${ }^{134}$ Maârif Salnameleri ile diğer kayıtlar arasında öğrenci sayılarında görülen farkın sebebi, okulda resmî kaydı olmayan öğrencilerin bulunması ve bunların salnâmelerde belirtilmemesi olmalıdır.

1902-1903 ders yılında okulda eğitim gören 204 öğrencinin milliyetlere göre dağılımı şöyledir: 152 Ermeni, 36 Rum, 12 Arap, 2 Türk, 1 Kürt ve bir de İtalyan. ${ }^{135}$ Bu ögrencilerin, 86'sı Gregoryen, 7l'i Protestan, 39'u Ortodoks ve 6'sı da Katolik mezheplerine mensuptur. ikisinin ise okula kısa süreli devam eden Müslüman öğrenciler olduğu görülmektedir. ${ }^{136}$ Buradan mevcut 12 Arap öğrencinin Hristiyan Arap olduğu anlaşılmaktadır. Ayrıca okula Hristiyanlardan başka Türk ve Kürt gibi Müslüman öğrencilerin de alınmış olması önemli bir husustur. 1907 yılında ülkedeki tüm Amerikan okulları hakkında hazırlanan bir raporun Tarsus ile ilgili kısmında, Tarsus Amerikan Okulu'nda tamamı Ermeni ve Protestan olan 200'den fazla öğrencinin eğitim gördüğü ve Müslüman öğrenci bulunmadığı belirtilmektedir. ${ }^{137}$ 1914-1915 ders yılında ise okula kayıt yaptıran 260 öğrenciden 35 'inin Müslüman olduğu görülmektedir. ${ }^{138}$

St. Paul Enstitüsü olan okulun adı 1915 yılında St. Paul Koleji olarak değiştirilmiştir. ${ }^{139}$ 1. Dünya Savaşı́nın en şiddetli bir şekilde devam ettiği bu tarihte Mersin'deki Amerikan Konsolosluğu ile yapılan yazışmalar neticesinde okul bir süre Osmanlı askerleri için kısa bir süre kışla olarak kullanılmıştır. ${ }^{10} 1$. Dünya Savaşı yıllarında ve Millî Mücadele sırasında sıkıntılı zamanlar geçiren okul, zaman zaman kapanma durumuna kadar gelmiştir. Bu yillarda okulun

\footnotetext{
${ }^{133}$ Kocabaşoğlu, Anadolu'daki Amerika, s. 202.

${ }^{134}$ Maârif Salnâmeleri, 1316, s. 844, 845; 1317, s. 942, 943; 1318, s. 1044, 1045; 1319, s. 270, 271.

${ }^{135}$ Kocabaşoğlu, Anadolu'daki Amerika, s. 202.

${ }^{136}$ Johnson, “St. Paul Okulu'ndan Tarsus Amerikan Koleji'ne...", s. 33

${ }^{137}$ BOA. Y.PRK.MF. 5/20.

${ }^{138}$ Bartholomew, A History of Tarsus American School, s. 22.

${ }^{139}$ Bartholomew, A History of Tarsus American School, s. 22.

${ }^{140}$ BOA. HR.SYS. 2415/53.
} 
öğrenci sayısında hayli azalma olduğu görülmektedir. Savaş yıllarında okulun fiziki yapılarında da bir kısım tahribatlar olmuştur. ${ }^{141}$

1893 yılından beri okul müdürlüğünü yürüten Dr. Christie, 1920 yılında 77 yaşında iken görevinden ayrılmış ve yerine Paul E. Nilson tayin edilmiştir. ${ }^{142}$ Bay Nilson'un müdürlük yaptığı 1920-1925 yılları, okulun öğretmen kadrosunun ve müfredatının kökten değiştiği dönemdir.

1. Dünya Savaşı́nda sonra Tarsus'un Fransızlar tarafından işgali sırasında şehirde bulunan Ermeniler, Fransızlarla işbirliği yaparak Türk halkını zor durumda bırakmıştır. Bunun üzerine şehri Fransız işgalinden kurtarmak amacıyla başlatılan Millî Mücadele döneminde, çoğunlukla Ermeni öğrencilere hizmet vermekte olan St. Paul Koleji de hâliyle eskisi gibi rahat çalışma ortamı bulamamışır. Öğrenci sayısındaki düşüş nedeniyle okul zaman zaman kapanma durumuna gelmiştir. Hatta 1920 Mayısının başında okulun hem kolej hem de akademi bölümü kapandığı, okulda 30 yetim çocuk dışında öğrenci kalmadığı görülmektedir. Bunun üzerine Okul Müdürü Mr. Nilson'un çalışmaları, Adana'daki Yakın Doğu Yardım Örgütü ve Hristiyan Genç Erkekler Cemiyeti'nin katkıları ile 5 Haziran 1920 tarihinde St. Paul Enstitüsü bünyesinde bir meslek okulu açılmıştır. Kısa sürede sayıları 100'ü bulan öğrencilere, misyon derslerinin yanında hazırlanan atölyelerde dokumacılık, terzilik, marangozluk, ayakkabıcılık, kalaycılık gibi iş kollarında dersler verilmiş ve bu sayede işgal yılları boyunca okul açık kalabilmiştir. ${ }^{143}$

1. Dünya Savaşı ve Millî Mücadele yıllarında şehirdeki gayrimüslim nüfusunun azalmasına paralel olarak, okuldaki Müslüman öğrenci sayısında bir artış gözlenmektedir. Hatta gidişat bir süre sonra okulda hiç gayrimüslim öğrencinin kalmayacağını göstermiştir. Hâl böyle olunca da okul yönetimi, eğitim politikasında köklü bir değişikliğe giderek faaliyetlerini Müslümanlar üzerinde yoğunlaştırmıştır. Bu çalışmalarında da başarılı olmuştur. Nitekim 1923 yılında okulda mevcut 139 öğrenciden 94'ünün Türk olduğu görülmektedir. ${ }^{144}$ Aynı yılın sonbaharında Tarsus'a gelen Roger P. Matteson okulda Ermeni, Rum, Suriyeli Hristiyanlar ile birlikte Türk ve Arap Müslüman öğrencilerin de eğitim gördüğünü belirtmektedir. ${ }^{145}$

${ }^{141}$ Bartholomew, A History of Tarsus American School, s. 22, 27.

${ }^{142}$ Bartholomew, A History of Tarsus American School, s. 23.

${ }^{143}$ Paul F. Bobb, "The Tarsus Trades School", The Orient, VIl (57), 561.

${ }^{144}$ Sezer, Atatürk Döneminde Yabancı Okullar, s. 78.

${ }^{145}$ Roger P Matteson, Tarsus'taki Yıllarım (1923-1927), Tarsus 2007, s. 13. 
St. Paul Koleji, 1923 yılında Hristiyanlık propagandası yaptığı gerekçesiyle kapatılmıştır. ${ }^{16}$ Bu konudaki en ciddi suçlama, kampusta yapılan Hristiyan ayinlerine Türk çocuklarının da katılmış olmasıdır. Okul yönetimi tarafından kapatılma kararına itiraz edilerek, Müslüman öğrencilerden ve velilerinden kendilerinin zorla kiliseye getirilmediğine, tamamen kendi istekleriyle geldiklerine dair imzalı belgeler alınmış ve okulun tekrar açılması için müracaatta bulunmuştur. ${ }^{147} \mathrm{Bu}$ süreçte okulun yeniden açılması için Osmanlı makamlarının diplomatik yollarla baskı altına alındığı da görülmektedir. Batı Anadolu'daki Yunan zulmünü, hazırladığı raporla dünya kamuoyuna duyuran Amerikalı komutan Amiral Bristol bile Tarsus Amerikan Okulu'nun kapatılmasından duyduğu üzüntüyü Osmanlı makamlarına bildirmiştir. ${ }^{148}$

iki yıllık bir aradan sonra 29 Eylül 1925 tarihli ve 667/4047 numaralı emri âlî ile okulun tekrar açılmasına müsaade edilmiştir. ${ }^{149} \mathrm{Bu}$ tarihte okulun dinî geçmişinin en açık sembollerinden olan St. Paul Koleji ismi, Tarsus Amerikan Okulu olarak değiştirilmiştir. Ayrıca Türkiye Cumhuriyeti'nin millî eğitim sistemini benimseyerek tüm yurttaşların yararlanacağı bir eğitim programı uygulamaya başlamıştır. ${ }^{150}$

Tarsus Amerikan Okulu, kuruluşundan itibaren Cumhuriyet'in ilk yıllarına kadar büyük bir gelişim ve değişim göstermiştir. Bu süreçte okul, genel mânâda Osmanlı toplumundaki Hristiyan cemaatlerin ihtiyaçlarına yönelik olarak Tarsus ve çevre şehirlerden temin ettiği öğrencileri, akademik ve dinî eğitim ile yetiştiren bir Protestan mektebinden, Türkiye Cumhuriyeti'nin gençliğine lâik bir eğitim sunan, devlet denetiminde modern bir okul hâline gelmiştir. Ancak bu okullarla ilgili olarak, "içcerikler değişir, anlayışlar da değişebilir, ancak evrensel idealler sonsuza dek yaşar ${ }^{\prime \prime 5 l}$ kaidesinin hiçbir zaman göz ardı edilmemesi gerekir.

Fransız Okulları: XIX. Yüzyılın sonlarında, Tarsus'ta Fransızlara ait okullar da açılmıştır. Bunlardan biri Fransız Capucins Cemiyeti'ne ait olup paralı ve parasız bölümleri mevcuttur. Küçük Minare Mahallesi'nde yer alan bu okul, 1899

\footnotetext{
${ }^{146}$ Milli Eğitim Bakanlığı Özel Öğretim Genel Müdürlüğü Arşivi, Tarsus Amerikan Koleji Dosyası; Sezer, Atatürk Döneminde Yabancı Okullar, s. 78. Alan Bartholomew ve Brian Johnson ise okulun 1924 yılı Mayıs ayında kapatıldığını belirtmektedir.

${ }^{147}$ Johnson, "St. Paul Okulu'ndan Tarsus Amerikan Koleji'ne...", s. 36.

148 BOA. HR.IM. 140/105.

${ }^{149}$ MEB, Özel Öğretim Genel Müdürlüğ̈̈ Arşivi, Tarsus Amerikan Koleji Dosyası.

150 Adnan Şişman, XX. Yüzyıl Başlarında Osmanlı Devleti'nde Yabancı Devletlerin Kültürel ve Sosyal Müesseseleri, Ankara 2006, s. 44.

${ }^{151}$ Johnson, “St. Paul Okulu'ndan Tarsus Amerikan Koleji'ne ...”, s. 37.
} 
yılında hizmete girmiştir. Paralı bölümde (École Payante) Fransızca, Türkçe, Arapça ve Farsça ile genel şark tarihi ve coğrafyası, dil bilgisi ve fen bilimleri dersleri verilmektedir. Okulda 1912 yılında 24'ü Müslüman olmak üzere 60 öğrenci eğitim görmektedir. Aynı yıl 57 öğrencinin eğitim gördüğü parasız bölümde ise (École Gratuite) Türkçe ve Ermenice ders yapılmakta, ayrıca Fransızca kursları verilmektedir. ${ }^{152}$

Tarsus'ta Fransız Sainte-Famille Rahibeleri Cemaatine ait bir de kız okulu ve çocuk bakımevi bulunmaktadır. Bu okul da 1899 yılında açımış olup Kızılmurad Mahallesi'nde yer almaktadır. Hem yatılı hem de parasız gündüzlü eğitim veren okulun bünyesinde çocuklara Fransızca öğretilen bir de çocuk bakımevi mevcuttur. 1912 yılında 6 yatılı öğrencinin bulunduğu okulda, 10'u Müslüman olmak üzere toplam $200 \mathrm{kız}$ öğrenciye eğitim verildiği görülmektedir. ${ }^{153}$

Bu okul 19 Aralık 1918 tarihinde Tarsus'u işgal eden Fransız askerleri için kışla olarak kullanılmıştır. Savaşın bitmesinden sonra ise kısa bir süre Türk Kız Okulu ardından da Türk Ocağı olarak hizmet vermiştir. ${ }^{154}$

Ruhsatsız Olarak Faaliyet Gösteren Okullar: 1869 yılında çıkarılan Maârif-i Umûmiye Nizamnâmesi ile tüm yabancı kurumlara ruhsat alma zorunluluğu getirilmiştir. Ancak misyonerler, bağlı bulundukları devletlerin siyasi nüfuzunu kullanarak irade-i seniyye çıkmasını beklemeksizin müesseseleri açmakta bir mahzur görmemişlerdir. Daha sonra da okullarına ruhsat alabilmek için diplomatik unsurları devreye sokup bir nevi Osmanlı hükümetini ruhsat vermeye mecbur bırakmışlardır. Tarsus'ta bulunan tek ruhsatlı Amerikan Protestan Okulu olan St. Paul Enstitüsü de böyle bir oldubitti ile ruhsatlandırılmıştır. Hatta bu konuda irade-i seniyye çıkmamış, okul Maârif Vekâleti'nin verdiği ruhsatnâme ile sonradan resmiyet kazanmıştır. Ancak Tarsus'ta bulunan tek Amerikan menşeli Protestan kuruluşu bu okul değildir.

Mersin'deki Amerikan Okulu'nun müdürü olan Dr. David Metheny, Tarsus'ta yoğun olarak yaşayan Nusayrîler arasında Protestanlı̆̆ı yaymak amacıyla, yaşları 8 ile 15 arasında değişen Nusayrî çocuklarını, yasak olmasına rağmen okuluna almış, hatta bir kısmını da gizli yollarla Amerika'ya göndermiştir. Metheny'nin Tarsus'taki işlerinin ise aslen Cebel-i Lübnanlı ve Osmanlı teb'asından olan Yusuf adında bir Protestan'ın yürüttüğü

\footnotetext{
${ }^{152}$ Adnan Şişman, XX. Yüzyıl Başlarında Osmanlı Devleti'nde..., s. 173.

${ }^{153}$ Şişman, XX. Yüzyıl Baslarında Osmanlı Devleti'nde..., s. 174.

${ }^{154}$ Erdal ilter, içel'de Ermeni Faaliyetleri, Ankara 1974, s. 77.
} 
görülmektedir. ${ }^{155}$ Yusufun önceleri, Tarsus'un özellikle Musalla ve Ömerli Mahallelerinden, ikna ettiği Nusayrî ailelerin kız çocuklarını, Mersin'e Metheny'nin okuluna gönderdiği belirlenmiştir. Bu konuda tedbir alınması üzerine Yusuf, Metheny'nin talimatı ile 1896 yılında Tarsus'taki evinin bir odasını okul hâline getirip burada 4'ü kız, 8'i erkek, altı yedi yaşlarında 12 çocuğa Protestanlık eğitimi vermeye başlamıştır. Yusufun evinde yürüttüğü bu faaliyetten yedi sekiz ay sonra haberdar olunmuş, okul kapatılarak gerek Yusuf, gerekse de çocuklarını bu okula gönderen Müslüman aileler hakkında gerekli işlemler yapılmıştır. ${ }^{156}$

Tarsus'ta 1901 yılında iki yeni ruhsatsız okul açılmıştır. Bu okullardan birisinin kime ait olduğu bilinmemekle birlikte diğerinin Mersin'deki Amerikan Misyonerlerine ait olduğu tespit edilmiştir. Bunun üzerine 5 ay önce eğitime başlayan, öğretmen ve öğrencileri Osmanlı teb'ası olan bu okulun ruhsatsız olduğu, hatta usulü dairesince bir irade-i seniyye ve ruhsat-ı resmiye müracaatı dahi olmadığı gerekçesiyle faaliyetlerine izin verilemeyeceği Amerika'nın Mersin Konsolosluğu'na bildirilmiştir. ${ }^{157}$

Amerikalı Protestanlar tarafından bir diğer okul açma girişimi de 1910 yılında olmuştur. Kiralık bir binada önceden açılmış olan okul bu tarihte kapatılınca, müdürü tarafından ruhsat alabilmek ve okulu yeniden açabilmek için müracaatta bulunulmuştur. Mahallinde yapılan inceleme neticesinde hazırlanan raporda; okulun ibtidaî statüsünde açıldı̆̆ ancak daha sonra Protestan Mezhebi üzerine eğitim veren bir okul hâline geldiği, bu durumun da diğer mezheb mensubu Hristiyanlar tarafından hoş karşılanmadığı gerekçesiyle kapatıldığı belirtilmiştir. Ancak okulun mekâtib-i husûsiye olarak Maârif-i Umûmiye Nizamnâmesi'nin 129. Maddesi ahkâmına uygun tedrisat yapması halinde diğer Amerikan müesseseleri gibi muamele görmesinde bir sakınca görülmemiş ve 30 Ağustos 1910 tarihinde ruhsatı verilmiştir. ${ }^{158}$ Böylece Tarsus'ta Amerikalı Protestanlara ait resmî okul sayısı ikiye çıkmıştır. Ancak resmî ruhsatı aldıktan sonra okulun tekrar açılıp açılmadı̆̆ı, açıldıysa da ne zamana kadar açık kaldığı konusunda ise herhangi bir bilgi bulunmamaktadır.

${ }^{155}$ BOA. MF.MKT. 237/20; A. MKT. МHM. 700/5.

${ }^{156}$ BOA. MF.MKT. 340/38.

${ }^{157}$ BOA. MF.MKT. 612/14; BOA. DH.MKT. 469/69.

${ }^{158}$ BOA. I.MF. 16/1328 Ş-12. 


\section{Sonuç}

Tanzimat'tan beri eğitim-öğretim alanında yapılanlara bakıldığında, Osmanlı reformcularının eğitimi ihmal etmedikleri ve gereken sslahatları yapmaya gayret ettikleri görülmektedir. Bünyesinde gayrimüslim ve gayr-i Türk unsurları barındıran sıradan bir Anadolu şehir olan Tarsus'ta da eğitim alanında yapılan ıslahatların neticelerini görmek mümkündür.

$\mathrm{Bu}$ çalışmada, değişik kaynaklardan elde edilen bilgiler ışığında, Tanzimat'tan Cumhuriyet'e Tarsus'ta eğitim öğretim kurumları ile ilgili veriler ortaya konmuştur. Bu süreçte eğitim sisteminde yapılan ıslahatların en yoğun olarak uygulanmaya başlandığı ve eğitim alanında en fazla gelişmenin kaydedildiği dönemin Sultan Il. Abdülhamid'in saltanat yılları olduğunu söylemek mümkündür.

Tarsus'ta modern eğitim kurumları olan ibtidaî mektepler ve rüşdiyelerin bu dönemde hızla yayılmasıyla birlikte, klasik eğitim kurumlarının etkinliğini yitirdiğini söylemek doğru olmaz. Aksine medreselerin sayısında bir artış olduğu ve 1881 yılında 19 olan medrese sayısının 1902 yılında 36'ya kadar çıktı̆̆ görülmektedir. Hatta Cumhuriyet'in ilân edildiği yıl bile Darü'l-Hilâfe adıyla yeni bir medrese yapılmasının kararlaştırılması, medrese eğitiminin Tarsus'ta hâlâ revaçta olduğunu göstermektedir.

Tarsus'ta en üst dereceli Müslüman okulu 1863 yılında açlan Tarsus Rüşdiyesi'dir. Bu okulun kuruluşuna öncülük eden ve açılması için kendi mülkünü vakfeden kişi Tarsus Müftüsü Ahmed Hilmi Efendi'dir. Burada Avrupaî tarzda eğitim veren modern bir okul hüviyetinde olan rüşdiye mektebinin açılmasına bir ilmiye mensubunun öncülük etmesi ve bu uğurda da bir hayli mesai harcaması dikkate değer bir husustur.

1905-1906 sayımında Tarsus'un genel nüfusu 59.675 kişi olarak tespit edilmiştir. Bu tarihte nüfusun 4.207 ile ancak \%7.05'lik bir bölümünü gayrimüslimler oluşturmaktadır. Bu dönemde şehirde mezheplerine göre ayrı ayrı olmak üzere, Ermeni, Rum ve Marunîlere ait birçok eğitim kurumu bulunmaktadır. Azınlıkların bu okullarda büyük bir özgürlük içerisinde çocuklarına eğitim verdikleri görülmektedir.

Tarsus'ta bulunan en üst düzey eğitim kurumu Amerikan misyonerlerinin Anadolu'daki en önemli okullarından biri olan St. Paul Enstitüsü (Tarsus Amerikan Okulu)'dür. 1888 yılında açlan bu okul, önceleri özellikle Ermeni çocuklarına eğitim verirken, daha sonra yasak olmasına rağmen Müslüman çocukları da kabul etmeye başlamıştır. Okul bünyesinde bulunan ve Genç 
Hristiyan Erkekler Cemiyeti (Y.M.C.A) adıyla bilinen misyonerlik örgütünün, yoğun bir şekilde misyonerlik faaliyeti yürüttüğü ve özellikle son dönemlerde bölgedeki Nusayri Arapları başta olmak üzere, diğer Müslüman unsurlardan bu misyonerlerin etkisinde kalanların olduğu görülmektedir.

Tarsus'ta idadî seviyesinde eğitim veren bir misyoner okulu bulunmasına rağmen, en yüksek dereceli Müslüman okulunun rüşdiye seviyesinde olması, Müslümanların eğitim alanında gayrimüslimlere nazaran zayıf kalmasına neden olmuştur. Bu nedenle Amerikan Okulu, verdiği eğitimle halk nazarında daha cazip hâle gelmiştir. Dönemin idarecileri de bu durumun farkına varmış ve Tarsus rüşdiyesinin idadî seviyesine yükseltilmesini teklif edilmişse de şehirde bir lisenin açılması Cumhuriyet yıllarına kalmışııı.

Osmanlı eğitim tarihindeki bu yenileşme ve değişim süreci, yeni Türk devletinin kurulmasından sonra da devam etmiştir. Cumhuriyet'in ilanından sonra Eğitimin kademeleri yeniden düzenlenmiş, medreseler kapatılmış, eskiden beri kontrol altında tutulamayan azınlık ve yabancı okulları tek bir iradeye bağlanmış ve böylelikle yıkıcı faaliyetleri engellenmiştir. Tarsus da bu gelişmelerden nasibini almış, Osmanlı döneminden beri faaliyet gösteren okulların isimleri ve uyguladıkları eğitim programları Cumhuriyet'in ilk yıllarında değiştirilmiştir.

Tarım, ticaret ve sanayi alanında özellikle XIX. yüzyılın ikinci yarısından itibaren büyük bir gelişme gösteren Tarsus şehri, bu dönemde eğitim ve kültür alanında da oldukça hızlı bir değişimin içerisine girmiştir. Özellikle yabancı eğitim kurumlarında görülen bu gelişme ve eğitim çeşitliliği, sıradan bir Osmanlı şehrinde farklı din ve kültür unsurlarına sağlanan eğitim özgürlüğünün boyutlarını göstermesi açısından da oldukça önemlidir.

\section{KAYNAKÇA}

\section{Süreli Yayınlar}

Adana Vilâyet Salnâmeleri (AVS), 1294, 1299, 1308, 1309, 1312, 1319, 1320.

Maârif Salnâmeleri, 1316, 1317, 1318, 1319, 1321.

Annuaire Oriental du Commerce, Constantinopole, 1905.

Tarsus gazetesi

\section{Arşivler}

Tarsus Sakarya ilköğretim Okulu Arşivi (TSiOA):

Erkek Numune Mektebi sene sonu imtihan cetvelleri.

Menba-1 İrfan Mektebi sene sonu imtihan cetvelleri.

Rehber-i Füyûz Mektebi sene sonu imtihan cetvelleri.

Tarsus Rüşdiyesi sene sonu imtihan cetvelleri. 
Milli Eğitim Bakanlı̆̆ı Özel Öğretim Genel Müdürlüğü Arşivi,

Tarsus Amerikan Koleji Dosyası

Başbakanlık Osmanlı Arşivi (BOA),

MF. MKT. (Maârif Nezâreti Mektûbî Kalemi): Nr. 1/41, 1026/36, 1033/75, 1041/27, 1332/27, 158/37, 189/111, 193/49, 195/10, 2/138, 237/20, 275/71, 279/52, 304/5, 340/38, 396/47, 598/41, 599/12, 600/34, 612/14, 617/13, 939/48.

DH. MKT. (Dahiliye Nezareti Mektubî Kalemi): Nr. 1131/82, 1300/16, 1408/68, 2073/2, 2336/30, 2728/52, 469/69, 598/41, 818/20.

i.DH. (İrade Dahiliye): Nr. 1217/95284, 1309/1311 Ca-40, 1428/1322.

A. MKT. MHM. (Bâb-1 Asâfî Mektûbî Mühimme): Nr. 700/5, 512/14.

HR. TO. (Hâriciye Tercüme Odası): Nr. 148/101, 148/84.

Y. PRK. MF. (Yıldız Perakende Maârif Nezâreti): Nr. 4/36, 5/20.

Y.MTV. (Yıldız Mütenevvî Marûzât), Nr. 306/83.

BEO. (Bâb-1 Âli Evrak Odası Belgeleri), Nr. 325/24341.

HR. iM. (Hâriciye Nezâreti ìstanbul Murahhasığı), Nr. 140/105.

HR. SYS. (Hâriciye Nezâreti Siyasî), Nr. 2415/53.

i. AZN. (Hâriciye Tercüme Odası), Nr. 114/1331 Za-18.

i.MF. (Irade Maârif), Nr. 16/1328 Ş-12.

MVL. (Meclis-i Vâlâ), Nr. 650/38.

Y.A.HUS. (Yıldız Sadâret Husûsî Marûzât), Nr. 335/67.

Y.A.RES. (Yıldız Sâderet Resmî Marûzât), Nr. 123/65.

\section{Kitaplar ve Makaleler}

Ahmed Şerif. Anadolu'da Tanin (Birinci Gezi). (Haz. Çetin Börekçi), ìstanbul 1977.

AKYüZ, Yahya. Türk Ë̆itim Tarihi; M.Ö.ıoo-M.S.2010. Pegem Yay., Ankara 2010.

BALTACl, Cahit. XV-XVI. Asirlarda Osmanlı Medreseleri. İrfan Yay, ìstanbul 1976.

BARTHOLOMEW, Alan A. A History Of Tarsus American School (1888-1988). Redhouse Prese, Tarsus 1988, s. 12, 13;

BilGGiLi, Ali Sinan. Osmanlı Döneminde Tarsus Sancağı ve Tarsus Türkmenleri. Kültür Bakanlığı Yay., Ankara 2001.

BOBB, Paul F. "The Tarsus Trades School”. The Orient, 29 December 1920, VII (57).

CUiNET, Vital. La Turquie d'Asie II, Paris 1892.

DAVis, Edwin John. Life In Asiatic Turkey. London 1879.

Evliya Çelebi. Seyahatnâme. (Haz. Yücel Dağlı-Seyit Ali Kahraman-Robert Dankoff), Yapı Kredi Yay., (9. Kitap), ìstanbul 2005.

JOHNSON, Brian. "St. Paul Okulu'ndan Tarsus Amerikan Koleji'ne Bir Okulun Dönüşümü”. Toplumsal Tarih, Şubat 2006, sayı: 146, 32-37.

KARATAŞ, Yakup. Sultan II. Abdülhamid Döneminde Erzurum. (Yayımlanmamış Doktora Tezi), Atatürk Üniversitesi Sosyal Bilimler Enstitüsü, Erzurum 2010.

KOCABAŞOĞLU, Uygur. “Amerikan Okulları". Tanzimat'tan Cumhuriyet'e Türkiye Ansiklopedisi, istanbul 1985, 11, 495-500.

KODAMAN, Bayram. Abdülhamid Devri Eğitim Sistemi. TTK Yay., Ankara 1999.

Mahmud Cevad İnbü'ş Şeyh Nâfi. Maârif-i Umumiye Nezâreti Tarihçe-i Teşkîlât ve ícraatı -XIX. Asır Osmanlı Maârif Tarihi- (Haz. Taceddin Kayaoğlu), Yeni Türkiye Yay., Ankara 2001.

MATTESON, Roger P. Tarsus'taki Yıllarım (1923-1927). Aratos Kitaplığı Kültür Dizisi-8, Tarsus 2007.

POLAT, ilknur. "Osmanlı İmparatorluğu'nda Açılan Amerikan Okulları Üzerinde Bir İnceleme". Belleten, Lll (203), 628-652.

SEZER, Ayten. Atatürk Döneminde Yabancı Okullar (1923-1938). TTK Yay. Ankara 1999. 
$354{ }^{*}$ TAED 47

S. UĞUZ

Şemseddin Sami. Kamus-ı Türkî IV. ikdam Matbaası, Dersaadet 1317.

ŞiŞMAN, Adnan. XX. Yüzyıl Başlarında Osmanlı Devleti'nde Yabancı Devletlerin Kültürel ve Sosyal Müesseseleri. Atatürk Araştırma Merkezi Yay., Ankara 2006.

TEKELi, ilhan. “Tanzimat'tan Cumhuriyet'e Eğitim Sistemindeki Değişmeler”. Tanzimat'tan Cumhuriyet'e Türkiye Ansiklopedisi, iletişim Yay., ìstanbul 1985, 11, 456-475.

ÜREKLi, Fatma. “Tanzimat Dönemi Osmanlı Eğitim Sistemi Ve Kurumları”. Manas Üniversitesi Sosyal Bilimler Dergisi, 2002-3, 382-406.

VAHAPOĞLU, M. Hidayet. Osmanlı'dan Günümüze Azınlık ve Yabancı Okullar. Boğaziçi Yay., istanbul 1992

YILDIZ, Özgür. Misyonerlik ve Amerikan Board Teşkilâtı. IQ Kültür Sanat Yay., İstanbul 2009, s. 53.

YILMAZ, Metin ve diğer. Cumhuriyet Öncesi ve Cumhuriyet Sonrası liçel'de Ë̆itim. yyy: Mersin 1998. 